Check for updates

Cite this: RSC Adv., 2019, 9, 40368

Accepted 26th November 2019

DOI: $10.1039 / \mathrm{c} 9 \mathrm{ra09762g}$

rsc.li/rsc-advances

\section{Total synthesis of squafosacin F: stereodivergent approach to mono-tetrahydrofuran acetogenins $\uparrow$}

\author{
Koichiro Ota, (D)* Sumika Kohno, Tomoko Yamashita, Atsuko Miura, Kazuo Kamaike \\ and Hiroaki Miyaoka (DD*
}

Annonaceous acetogenins have a wide range of potential biological activities. The development of simple and diversity-oriented approaches to their synthesis is therefore important. We have achieved the first total synthesis of squafosacin $\mathrm{F}$ and assigned its absolute configuration. The key steps were an acid-mediated tandem intramolecular double cyclization to build the hydroxy-flanked mono-tetrahydrofuran core and decoration with the desired functionalities of the target natural product via highly stereoselective reactions.

\section{Introduction}

In the past 35 years a vast number of annonaceous acetogenins have been isolated from the leaves, seeds, roots, and bark of tropical plants of the Annonaceae family. ${ }^{1}$ Acetogenins consist of four substructures, namely an $\alpha, \beta$-unsaturated- $\gamma$-lactone, one to three tetrahydrofuran (THF) units with flanking hydroxy groups, a long alkyl tail, and an alkyl spacer linking the $\gamma$ lactone and tetrahydrofuran moieties. Annonaceous acetogenins are well-known compounds with potent biological activities, e.g., antiviral, antineoplastic, antimalarial, immunosuppressive, and anticoagulant effects. ${ }^{2}$ Many of the biological activities of acetogenins are attributed to their inhibitory effects on mitochondrial NADH-ubiquinone oxidoreductase (complex I). ${ }^{3}$ Detailed structure-activity relationship studies have shown that the $\gamma$-lactone moiety and the hydroxyflanked tetrahydrofuran moiety alone do not inhibit mitochondrial complex I activity, but inhibitory activity occurs when these components are linked by an alkyl spacer. The presence of a polar functional group such as a hydroxy group on the alkyl spacer is not necessary. A chain length of $\mathrm{C}_{13}$ is important for achieving the most potent inhibitory activity. ${ }^{4}$

cis-Solamin is a particularly active mono-tetrahydrofuran acetogenin. ${ }^{5}$ It was isolated from a root extract of Annona muricata L. and its structure was determined by Cavé et al. in 1998. It has a C13 spacer and therefore shows strong mitochondrial complex I inhibitory activity. Because of its unique structure and biological activity, many studies of syntheses of this compound and its analogs have been performed. ${ }^{6}$ In 2018 , we reported its formal synthesis via tandem cyclization of a diepoxy

School of Pharmacy, Tokyo University of Pharmacy and Life Sciences, 1432-1 Horinouchi, Hachioji, Tokyo 192-0392, Japan. E-mail: miyaokah@toyaku.ac.jp; Fax: +81-42-676-3073; Tel: +81-42-676-3080

$\dagger$ Electronic supplementary information (ESI) available. CCDC 1950967. For ESI and crystallographic data in CIF or other electronic format see DOI: 10.1039/c9ra09762g ester to achieve stereoselective formation of the hydroxy-flanked mono-tetrahydrofuran core. ${ }^{7}$

In 2008, Wu et al. isolated squafosacin $\mathrm{F}$ from Annona squamosa $\mathrm{L}$. and determined its structure. This compound is a mono-tetrahydrofuran acetogenin with a C13 spacer (Fig. 1). ${ }^{8}$

Squafosacin $\mathrm{F}$ is a diastereomer of cis-solamin but its stereochemistry is still uncertain. The signals at $\delta_{\mathrm{H}} 3.85(3 \mathrm{H}) / \delta_{\mathrm{C}}$ 83.2, 82.1, and 71.8, and $\delta_{\mathrm{H}} 3.40(1 \mathrm{H}) / \delta_{\mathrm{C}} 74.3$ in the ${ }^{1} \mathrm{H}$ and ${ }^{13} \mathrm{C}$ NMR spectra of this compound indicate that squafosacin $\mathrm{F}$ has a tetrahydrofuran moiety flanked by two hydroxy groups in threo and erythro configurations. ${ }^{9}$ The relative configuration in the important tetrahydrofuran region could not be determined because of the complex signals at C-17 and C-18, and it was not possible to determine whether the configuration was threo/cis/ erythro or threo/trans/erythro. However, the absolute configurations of the oxymethine group were identified as $15 S$ and $20 S$ by using the modified Mosher's method. ${ }^{10}$ This showed that the tetrahydrofuran was in a cis configuration. On the basis of this analysis, the absolute configuration of squafosacin $\mathrm{F}$ was identified as either $15 S / 16 S / 19 R / 20 S$ (1) or $15 S / 16 R / 19 S / 20 S$ (2) (Fig. 2). Although squafosacin $\mathrm{F}$ is expected to have potent biological activity, similar to that of cis-solamin, the synthesis of squafosacin $\mathrm{F}$ has not yet been reported. We undertook the synthesis of squafosacin $\mathrm{F}$ to prove that our developed tandem cyclization, which was used in the formal synthesis of cis-solamin, ${ }^{7}$ provides a comprehensive method for monotetrahydrofuran acetogenin synthesis. Here, report the first total synthesis of squafosacin F and determination of its absolute configuration.

\section{Results and discussion}

Our retrosynthetic analysis of the candidate compound $\mathbf{1}$ is shown in Scheme 1. We envisioned that 1 could be obtained from terminal alkene A via a ruthenium-catalyzed Alder-ene reaction $^{11}$ with ethyl (S)-4-hydroxypent-2-ynoate (3). We 


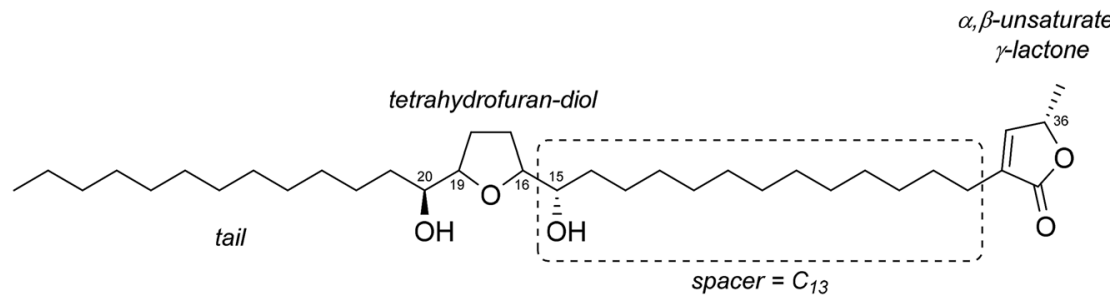

Fig. 1 Structure of mono-THF acetogenin squafosacin F.

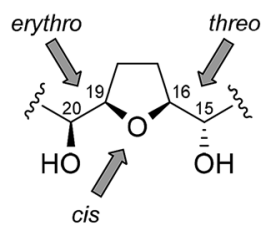

1

$(15 S, 16 S, 19 R, 20 S)$

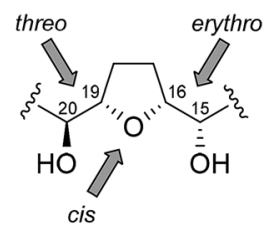

2

$(15 S, 16 R, 19 S, 20 S)$
Fig. 2 Possible structures of erythro/cis/threo tetrahydrofuran-diol.

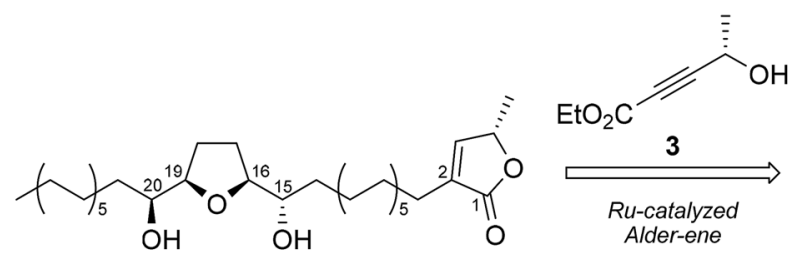
1
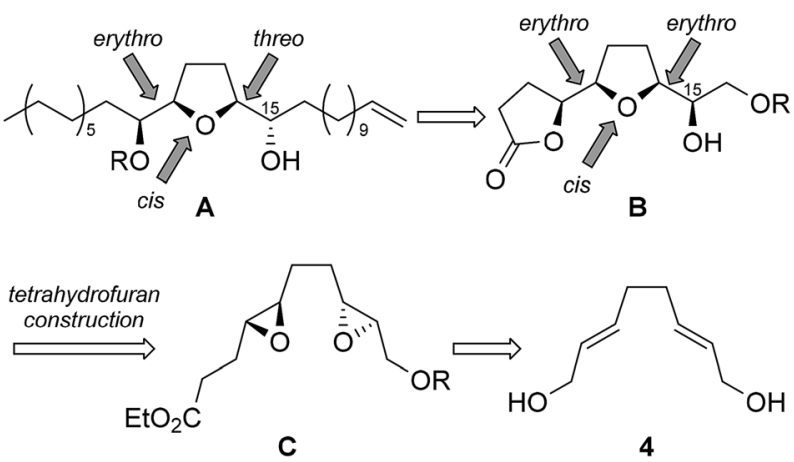

Scheme 1 Retrosynthetic analysis of 1.

anticipated that the synthesis of threo/cis/erythro tetrahydrofurandiol A could achieved by elongation of the appropriate alkyl tail and introduction of the spacer unit via a stereoinversion at the C-15 position to give erythro/cis/erythro tetrahydrofuran- $\gamma$-lactone B. We expected that tetrahydrofuran- $\gamma$ lactone $\mathbf{B}$ could be obtained by using our developed acidmediated tandem reaction for opening of the epoxide group in diepoxy ester $\mathbf{C}$, which in turn could be synthesized by stepwise asymmetric epoxidation from the known allylic alcohol 4. $^{12}$

The synthesis of $\mathbf{1}$ started with the stereoselective synthesis of diepoxy ester 7 (Scheme 2). The symmetric E,E-diallylic alcohol 4 (ref. 12) was transformed to a monoacetate, which was then converted to epoxy alcohol 5 via a Sharpless asymmetric epoxidation under standard conditions. ${ }^{13}$ The optical purity of 5 was determined to be $>95 \%$ ee from the ${ }^{1} \mathrm{H}$ NMR spectrum in the presence of Chirabite-AR. ${ }^{\mathbf{1 4}}$ Protection of the primary hydroxy group in epoxy alcohol $\mathbf{5}$ with a methoxymethyl group and subsequent deacetylation gave $E$-allylic alcohol 6, which was converted to an epoxy alcohol in $86 \%$ yield via sharpless asymmetric epoxidation. We obtained the unsaturated ester with excellent selectivity $(>95: 5, E / Z)$ by oxidation and then a Wittig reaction. Unexpected problems arose during reduction of the resulting unsaturated ester. Initially, we attempted to hydrogenate the double bond by using $\mathrm{Pd} / \mathrm{C}$, but the main reaction was epoxide ring opening and almost no diepoxy ester 7 was obtained $(<5 \%$ yield). This problem was overcome by using a rhodium catalyst. ${ }^{15}$ The order of addition of the reagents was important. Blowing hydrogen into a suspension of the unsaturated ester and $\mathrm{Rh} / \mathrm{Al}_{2} \mathrm{O}_{3}$ in THF gave diepoxy ester 7 in moderate yield ( $51 \%$ ) but was accompanied by formation of an epoxide-opened byproduct. Slow addition of the unsaturated ester to a suspension of pre-hydrogen-adsorbed $\mathrm{Rh} / \mathrm{Al}_{2} \mathrm{O}_{3}$ in THF provided ester 7 in $80 \%$ yield over two steps from the epoxy alcohol. This suggests that hydrogen adsorption on the rhodium catalyst was not required for epoxide opening and that hydrogenation was faster than epoxide opening.

The ester was efficiently synthesized by catalytic hydrogenation using a rhodium catalyst with pre-stored hydrogen. NMR analysis of the diepoxy ester gave some unexpected results. In a previous study of cis-solamin synthesis, ${ }^{7}$ tandem cyclization

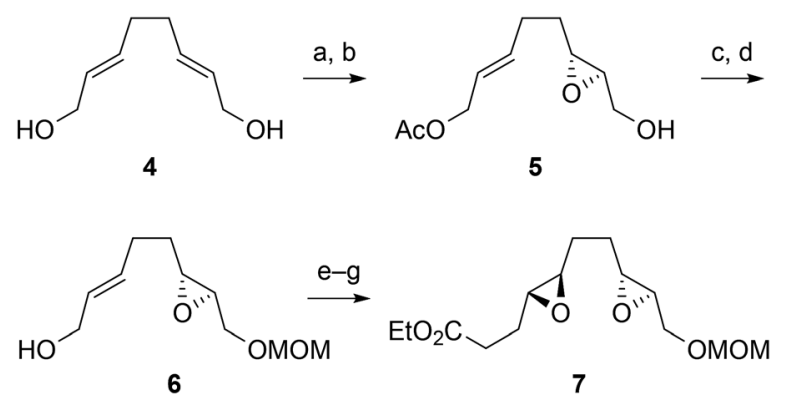

Scheme 2 Synthesis of diepoxyester 7. Reagents and conditions: (a) $\mathrm{Ac}_{2} \mathrm{O}$, pyridine, r.t., 52\%; (b) TBHP, D-(-)-DIPT, Ti(O'Pr) 4 , $4 \AA$ molecular sieves, $\mathrm{CH}_{2} \mathrm{Cl}_{2},-20{ }^{\circ} \mathrm{C}, 98 \%$ (>95\% ee); (c) $\mathrm{MOMCl}$, DIPEA, $\mathrm{CH}_{2} \mathrm{Cl}_{2}$, reflux; (d) $\mathrm{K}_{2} \mathrm{CO}_{3}, \mathrm{MeOH}$, r.t., $88 \%$ (2 steps); (e) TBHP, D-(-)-DIPT, $\mathrm{Ti}\left(\mathrm{O}^{\mathrm{i}} \mathrm{Pr}\right)_{4}, 4 \AA$ A molecular sieves, $\mathrm{CH}_{2} \mathrm{Cl}_{2},-20^{\circ} \mathrm{C}$, 86\%; (f) Dess-Martin periodinane, $\mathrm{NaHCO}_{3}, \mathrm{CH}_{2} \mathrm{Cl}_{2}$, r.t. then $\mathrm{Ph}_{3} \mathrm{P}=\mathrm{CHCO}_{2} \mathrm{Et}$, r.t.; (g) $\mathrm{H}_{2}$, $\mathrm{Rh} / \mathrm{Al}_{2} \mathrm{O}_{3}, \mathrm{THF}$, r.t., $80 \%$ (2 steps). 


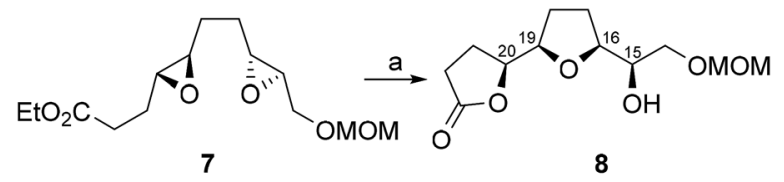<smiles>O=C1CCC(C2CCC(COC(=O)c3cc([N+](=O)[O-])cc([N+](=O)[O-])c3)O2)O1</smiles>

9

Scheme 3 Synthesis of tetrahydrofuran- $\gamma$-lactone 8 . Reagents and conditions: (a) 10-camphorsulfonic acid, $\mathrm{H}_{2} \mathrm{O}, \mathrm{CH}_{2} \mathrm{Cl}_{2}$, r.t., $91 \%$; (b) 3,5-dinitrobenzoic acid, WSC, DMAP, $\mathrm{CH}_{2} \mathrm{Cl}_{2}$, r.t.; (c) $\mathrm{BF}_{3} \cdot \mathrm{OEt}_{2}, \mathrm{Me}_{2} \mathrm{~S}$, $\mathrm{CH}_{2} \mathrm{Cl}_{2},-30{ }^{\circ} \mathrm{C}, 81 \%$ (2 steps).

caused by a small amount of an acid contaminant proceeded to form tetrahydrofuran- $\gamma$-lactone when NMR spectroscopic analysis of the corresponding diepoxy ester was performed in deuterated chloroform as the solvent. This observation triggered development of the acid-mediated tandem cyclization. However, in this case, diepoxy ester 7 was stable, despite the deuterated solvent, and no tetrahydrofuran- $\gamma$-lactone 8 was formed. This indicates that the acid sensitivity of the reaction using an $E, E$-diepoxide differed from that of the previously reported reaction using a $Z, Z$-diepoxide. Although a possible decrease in the reactivity was a concern, the tandem cyclization proceeded smoothly when $E$,E-diepoxy ester 7 was treated with 10-camphorsulfonic acid (0.2 equiv.) and water (1.0 equiv.) at room temperature in dichloromethane for $1.5 \mathrm{~h}$; tetrahydrofuran- $\gamma$-lactone $\mathbf{8}$ was obtained with controlled stereochemistry at the C-15, C-16, C-19, and C-20 positions (91\% yield; Scheme $3)$. The stereochemistry of $\mathbf{8}$ was confirmed by X-ray crystallographic analysis of the dinitrobenzoate $\mathbf{9},{ }^{16}$ which was obtained by condensation of 3,5-dinitrobenzoic acid, removal of the methoxymethyl protecting group, and concomitant 1,2-acyl migration (Fig. 3).

This transformation can be explained by the mechanism shown in Scheme 4. First, acidic hydrolysis of the ester

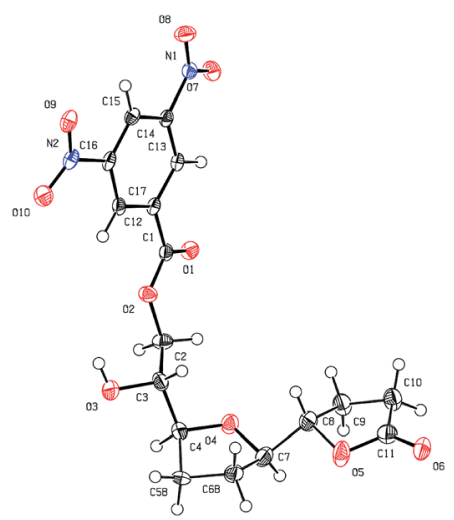

Fig. 3 ORTEP drawing of dinitrobenzoate 9.

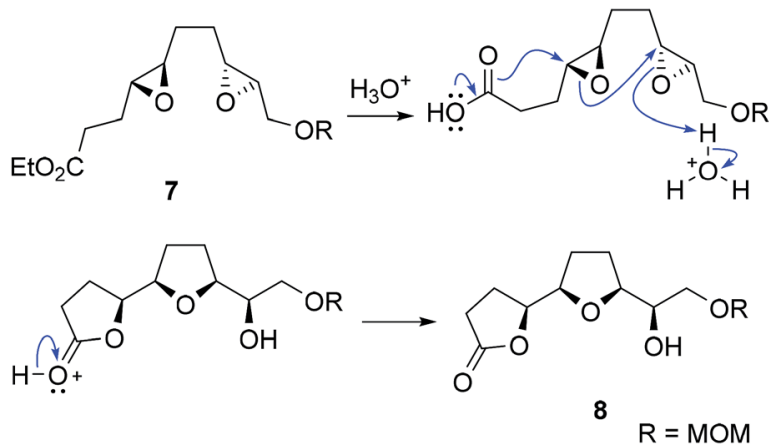

Scheme 4 Acid-catalyzed one-step construction of tetrahydrofurandiol.

generates a carboxyl group in situ. The protonated epoxide oxygen acts as a leaving group, which leads to a sequential intramolecular $\mathrm{S}_{\mathrm{N}} 2$-like cyclization of the carbonyl oxygen to form erythro/cis/erythro tetrahydrofuran- $\gamma$-lactone 8.

Having obtained tetrahydrofuran- $\gamma$-lactone 8 , we introduced the appropriate alkyl linker, spacer, and $\gamma$-lactone to achieve the synthesis of 1. First, we attached an alkyl linker to the tetrahydrofuran core. Half-reduction of $\mathbf{8}$ followed by a Wittig reaction of the resulting hemiacetal yielded an unsaturated alcohol as an inconsequential mixture (Scheme 5). Triol 10 was obtained by hydrogenation of the double bond, acid deprotection, protection as the acetonide derivative, and then treatment with acetic anhydride and pyridine to provide the corresponding acetate. Mild acidic deprotection of the acetonide and subsequent silylation of the resulting diol furnished the secondary alcohol, which underwent mesylation; subsequent treatment with
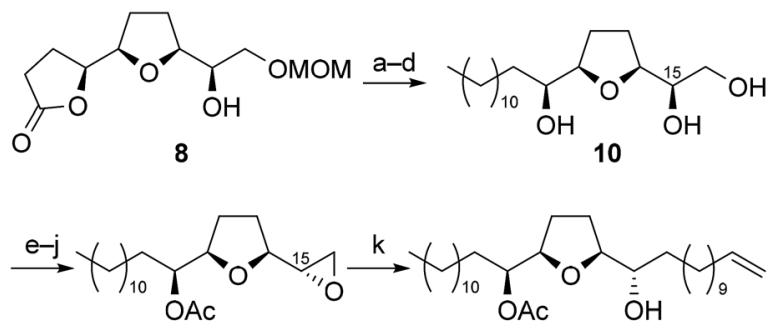

11

12

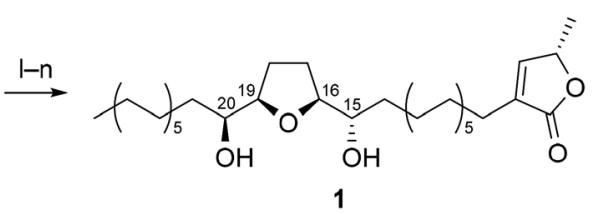

Scheme 5 Synthesis of 1. Reagents and conditions: (a) DIBAH, $\mathrm{CH}_{2} \mathrm{Cl}_{2}$, $-78{ }^{\circ} \mathrm{C}$; (b) nonyltriphenylphosphonium bromide, BuLi, THF, $0{ }^{\circ} \mathrm{C}$ to r.t.; (c) $\mathrm{H}_{2}, \mathrm{Pd} / \mathrm{C}, \mathrm{MeOH}$, r.t.; (d) $\mathrm{HCl}, \mathrm{MeOH}, 0{ }^{\circ} \mathrm{C}, 82 \%$ (4 steps); (e) 2,2dimethoxypropane, $\mathrm{pTsOH} \cdot \mathrm{H}_{2} \mathrm{O}$, r.t.; (f) $\mathrm{Ac}_{2} \mathrm{O}$, pyridine, r.t.; (g) $80 \%$ $\mathrm{AcOH}, 50{ }^{\circ} \mathrm{C}$; (h) $\mathrm{TBSCl}, \mathrm{Et}_{3} \mathrm{~N}, \mathrm{DMAP}, \mathrm{CH}_{2} \mathrm{Cl}_{2}$, r.t.; (i) $\mathrm{MsCl}, \mathrm{Et}_{3} \mathrm{~N}$, $\mathrm{CH}_{2} \mathrm{Cl}_{2}$, r.t.; (j) TBAF, THF, $50{ }^{\circ} \mathrm{C}, 87 \%$ (6 steps); (k) $\mathrm{CH}_{2}=\mathrm{CH}\left(\mathrm{CH}_{2}\right)_{9}$ $\mathrm{MgBr}, \mathrm{Cul}, \mathrm{THF},-60{ }^{\circ} \mathrm{C}, 79 \%$; (l) DIBAH, $\mathrm{CH}_{2} \mathrm{Cl}_{2},-78{ }^{\circ} \mathrm{C}$; (m) ethyl (S)4-hydroxypent-2-ynoate (3), $\mathrm{CpRu}\left(\mathrm{MeCN}_{3} \mathrm{PF}_{6}, \mathrm{DMF}, \quad\right.$ r.t.; (n) $\mathrm{TsNHNH}_{2}, \mathrm{NaOAc}$, THF/ $\mathrm{H}_{2} \mathrm{O}, 60^{\circ} \mathrm{C}, 65 \%$ (3 steps). 
Table 1 Comparison of the ${ }^{13} \mathrm{C} \mathrm{NMR}\left(\mathrm{CDCl}_{3}\right)$ spectroscopic data for natural squafosacin $\mathrm{F}$ and synthetic 1 and 2

\begin{tabular}{llll}
\hline Position & Natural squafosacin $\mathrm{F} \delta^{a}[\mathrm{ppm}]$ & Synthetic $1 \delta^{b}[\mathrm{ppm}]$ & 173.9 \\
\hline 1 & 173.9 & 173.9 & 134.2 \\
2 & 134.3 & 134.4 & 25.2 \\
3 & 25.3 & 25.2 & 27.3 \\
4 & 27.4 & 27.4 & $26.0-29.7$ \\
$5-13$ & $25.6-29.7$ & $25.7-29.7$ & $33.1^{c}$ \\
14 & $33.2^{c}$ & $34.2^{c}$ & 74.3 \\
15 & 74.4 & 74.5 & 83.3 \\
16 & 83.2 & 82.7 & 28.6 \\
17 & 28.6 & 28.4 & 25.5 \\
18 & 25.6 & 24.3 & 82.2 \\
19 & 82.1 & 82.2 & 71.4 \\
20 & 71.5 & 72.3 & $32.5^{c}$ \\
21 & $32.5^{c}$ & $33.1^{c}$ & $26.0-29.7$ \\
$22-29$ & $25.6-29.7$ & $25.7-29.7$ & 31.9 \\
30 & 31.9 & 31.9 & 22.6 \\
31 & 22.7 & 22.7 & 14.1 \\
32 & 14.1 & 14.1 & 148.8 \\
33 & 148.9 & 148.8 & 77.4 \\
34 & 77.4 & 77.4 & 19.2 \\
$a$ & 19.2 & 19.2 &
\end{tabular}

tetrabutylammonium fluoride at $0{ }^{\circ} \mathrm{C}$ for $10 \mathrm{~min}$ generated the alkoxide anion species in situ. The reaction mixture was warmed to $50{ }^{\circ} \mathrm{C}$ and then stirred at this temperature for $12 \mathrm{~h}$. Subsequent cyclization to a sulfonate moiety proceeded smoothly in a one-pot system to afford epoxide $\mathbf{1 1}$ with complete inversion of the configuration at $\mathrm{C}-15$. The conversion of epoxide 11 to 1 was performed by using the method reported by Brown et al. ${ }^{17}$ Introduction of the alkyl spacer into epoxide $\mathbf{1 1}$ was achieved by a copper-catalyzed Grignard reaction to give terminal alkene $\mathbf{1 2 .}$<smiles>CC(C)(C)C([C@H](O)[C@@H]1CC[C@@H]([C@H](O)CO)O1)C(C)(C)C</smiles>

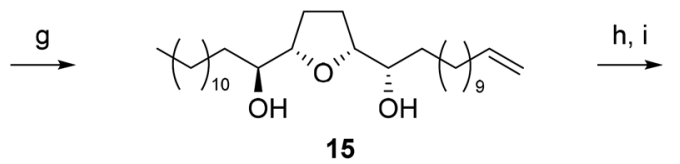<smiles>CC(CCC(C)(C)C)CC(C)(C)CC(O)[C@H]1CC[C@@H]([C@H](O)CC(C)(C)C)O1</smiles>

Scheme 6 Synthesis of 2. Reagents and conditions: (a) 2,2-dimethoxypropane, $p \mathrm{TsOH} \cdot \mathrm{H}_{2} \mathrm{O}$, r.t.; (b) $\mathrm{Ac}_{2} \mathrm{O}$, pyridine, r.t.; (c) $80 \% \mathrm{AcOH}$, $50{ }^{\circ} \mathrm{C}$; (d) $\mathrm{TBSCl}, \mathrm{Et}_{3} \mathrm{~N}, \mathrm{DMAP}, \mathrm{CH}_{2} \mathrm{Cl}_{2}$, r.t.; (e) $\mathrm{MsCl}_{1} \mathrm{Et}_{3} \mathrm{~N}, \mathrm{CH}_{2} \mathrm{Cl}_{2}$, r.t.; (f) TBAF, THF, $50{ }^{\circ} \mathrm{C}$, 75\% (6 steps); (g) $\mathrm{CH}_{2}=\mathrm{CH}\left(\mathrm{CH}_{2}\right)_{9} \mathrm{MgBr}$, Cul, THF, $-60{ }^{\circ} \mathrm{C}$, 77\%; (h) ethyl (S)-4-hydroxypent-2-ynoate (3), $\mathrm{CpRu}(\mathrm{MeCN})_{3} \mathrm{PF}_{6}$, DMF, r.t.; (i) $\mathrm{TsNHNH}_{2}, \mathrm{NaOAc}, \mathrm{THF} / \mathrm{H}_{2} \mathrm{O}, 60{ }^{\circ} \mathrm{C}$, $89 \%$ (2 steps).
Deacetylation of 12 and a subsequent ruthenium-catalyzed Alder-ene reaction ${ }^{\mathbf{1 1}}$ with ethyl $(S)$-4-hydroxypent-2-ynoate (3) afforded the corresponding $\gamma$-lactone. Finally, reduction of the isolated double bond by using $p$-toluenesulfonylhydrazide and NaOAc furnished 1 with the $15 S / 16 S / 19 R / 20 S$ configuration.

The ${ }^{1} \mathrm{H}$ NMR spectra of natural squafosacin $\mathrm{F}^{8}$ and synthetic compound $\mathbf{1}$ are similar. However, careful comparison of the ${ }^{13} \mathrm{C}$ NMR spectra revealed minor discrepancies at three positions, namely C-14: $\delta_{\mathrm{C}} 33.2$ vs. 34.2; C-18: $\delta_{\mathrm{C}} 25.6$ vs. 24.3; and C20: $\delta_{\mathrm{C}} 71.5$ vs. 72.3 (Table 1).

The differences between the ${ }^{13} \mathrm{C}$ NMR spectroscopic shifts were slight, therefore we synthesized another candidate compound, i.e., 2, from triol 13, which was an intermediate in our previous synthesis of cis-solamin, ${ }^{7}$ by using a similar reaction sequence to that shown in Scheme 6. Synthesis of 2 with the $15 S / 16 R / 19 S / 20 S$ configuration was successful. Comparison of the ${ }^{13} \mathrm{C}$ NMR spectra showed that the spectrum of 2 was a better match than that of $\mathbf{1}$ for the spectrum of natural squafosacin $\mathrm{F}$. The spectral and physical properties of 2, namely the ${ }^{1} \mathrm{H}$ and ${ }^{13} \mathrm{C}$ NMR spectra, IR spectrum, HRMS results, and optical rotation, perfectly matched those of natural squafosacin F. The first total synthesis of squafosacin F (2) had therefore been accomplished and its absolute configuration was identified as $15 S, 16 R, 19 S, 20 S, 36 S$.

\section{Conclusions}

In conclusion, a diversity-oriented synthetic approach enabled the first total synthesis of squafosacin F (2) and the absolute configuration was established with the help of a ${ }^{13} \mathrm{C} N \mathrm{NM}$ spectroscopic comparison of both possible configurations at C16 and C-19. The salient features of the developed synthesis are tandem cyclization of a diepoxy ester with a Brønsted acid and 1 
equiv. of water, introduction of a long alkyl linker and spacer, and $\alpha, \beta$-unsaturated- $\gamma$-lactone formation by a rutheniumcatalyzed Alder-ene reaction. In addition, our developed acidmediated tandem cyclization can be used to control the stereochemistry of the tetrahydrofuran moiety flanked by two hydroxy groups by selecting an appropriate configuration of the diepoxy ester. This synthetic method can be used to construct natural mono-tetrahydrofuran acetogenins with various configurations. We hope that this strategy will open up a new approach to the preparation of natural mono-tetrahydrofuran acetogenins and of various analogs with similar structures.

\section{Experimental section}

\section{General experimental procedures}

Melting points (mp) were measured using the Yanaco melting point apparatus MP-S3 and were uncorrected. Optical rotations were measured with a JASCO P-1030 polarimeter. IR spectra were recorded with a JASCO FT-IR/620 spectrometer. Single crystal X-ray diffraction was recorded using a MacScience Co., Ltd DIP 2020 Image Plate. ${ }^{1} \mathrm{H}$ and ${ }^{13} \mathrm{C}$ NMR spectra were recorded on a Bruker Biospin AVANCE III HD $400(400 \mathrm{MHz}$ for ${ }^{1} \mathrm{H}, 100 \mathrm{MHz}$ for ${ }^{13} \mathrm{C}$ ) and a Bruker Biospin AVANCE III HD 500 $\left(500 \mathrm{MHz}\right.$ for ${ }^{1} \mathrm{H}, 125 \mathrm{MHz}$ for ${ }^{13} \mathrm{C}$ ). The reported chemical shifts $(\delta)$ in parts per million (ppm) were relative to the internal $\mathrm{CHCl}_{3}$ (7.26 ppm for ${ }^{1} \mathrm{H}$ and $77.0 \mathrm{ppm}$ for ${ }^{13} \mathrm{C}$ ); the coupling constant $(J)$ values were measured in hertz. The coupling patterns are denoted as s (singlet), d (doublet), t (triplet), q (quartet), $\mathrm{m}$ (multiplet), and br (broad). HR-ESI-MS spectra were obtained using a Micromass LCT spectrometer with a time-of-flight (TOF) analyzer. Elemental analysis data were obtained using an Elementar Vario EL. Precoated silica gel plates with a fluorescent indicator (Merck 60 F254) were used for analytical and preparative thin-layer chromatography (TLC). Flash column chromatography was performed using Kanto Chemical silica gel 60N (spherical, natural) 40-50 $\mu \mathrm{m}$. All reagents (Aldrich, Kanto, TCI, and Wako) and solvents were of commercial quality and were used as received.

$(2 E, 6 E)-8-H y d r o x y o c t a-2,6-d i e n-1-y l$ acetate (16). To a stirred solution of (2E,6E)-octa-2,6-diene-1,8-diol (4) (1.00 g, 7.03 $\mathrm{mmol})$ in pyridine $(0.566 \mathrm{~mL}, 7.03 \mathrm{mmol})$ was added acetic anhydride $(0.665 \mathrm{~mL}, 7.03 \mathrm{mmol})$ at room temperature. After stirring the mixture for $5 \mathrm{~min}$, the reaction mixture was concentrated in vacuo. The residue was purified with flash column chromatography on silica gel (hexane/EtOAc $=4: 1$ to $0: 1)$ to give monoacetate 16 (668 $\mathrm{mg}, 52 \%$ yield) as a colorless oil, diacetate (445 mg, 28\% yield) as a colorless oil, and 4 (100 mg, 10\% recovered yield): $R_{\mathrm{f}} 0.25$ (hexane/EtOAc $=1: 1$ ); IR (neat) $\nu_{\max } 3417,3022,2926,2850,1740,1672,1236,1024 \mathrm{~cm}^{-1}$; ${ }^{1} \mathrm{H} \mathrm{NMR}\left(\mathrm{CDCl}_{3}, 400 \mathrm{MHz}\right) \delta 5.76(1 \mathrm{H}, \mathrm{m}), 5.68-5.65(2 \mathrm{H}, \mathrm{m})$, $5.59(1 \mathrm{H}, \mathrm{m}), 4.51(2 \mathrm{H}, \mathrm{dd}, J=0.6,6.4 \mathrm{~Hz}), 4.11-4.07(2 \mathrm{H}, \mathrm{m})$, 2.17-2.14 (4H, m), 2.06 (3H, s), $1.54(1 \mathrm{H}, \mathrm{brs}) ;{ }^{13} \mathrm{C} \mathrm{NMR}\left(\mathrm{CDCl}_{3}\right.$, $100 \mathrm{MHz}) \delta 170.9(\mathrm{C}), 135.4(\mathrm{CH}), 131.9(\mathrm{CH}), 129.7(\mathrm{CH}), 124.4$ $(\mathrm{CH}), 65.1\left(\mathrm{CH}_{2}\right), 63.6\left(\mathrm{CH}_{2}\right), 31.7\left(\mathrm{CH}_{2}\right), 31.4\left(\mathrm{CH}_{2}\right), 21.0\left(\mathrm{CH}_{3}\right)$; MS (ESI-TOF) $m / z 207[\mathrm{M}+\mathrm{Na}]^{+}$(100); HRMS (ESI-TOF) $\mathrm{m} / \mathrm{z}[\mathrm{M}+$ $\mathrm{Na}]^{+}$calcd for $\mathrm{C}_{10} \mathrm{H}_{16} \mathrm{O}_{3} \mathrm{Na} 207.0997$, found 207.0994; anal. calcd for $\mathrm{C}_{10} \mathrm{H}_{16} \mathrm{O}_{3}$ : C, 65.19; $\mathrm{H}$, 8.75. Found: C, 65.07; H, 8.80.
$(E)-5-((2 R, 3 R)-3-(H y d r o x y m e t h y l) o x i r a n-2-y l) p e n t-2-e n-1-y l$ acetate (5). To a cold $\left(-20{ }^{\circ} \mathrm{C}\right)$ suspension of $4 \AA$ molecular sieves $(2.79 \mathrm{~g})$ in $\mathrm{CH}_{2} \mathrm{Cl}_{2}(40.0 \mathrm{~mL})$ were added D-(-)-DIPT (0.478 mL, $2.27 \mathrm{mmol}), \mathrm{Ti}\left(\mathrm{O}^{\mathrm{i}} \mathrm{Pr}\right)_{4}(0.446 \mathrm{~mL}, 1.51 \mathrm{mmol})$, and TBHP (6.50 M solution in $\mathrm{CH}_{2} \mathrm{Cl}_{2}, 7.00 \mathrm{~mL}, 45.3 \mathrm{mmol}$ ). After stirring the mixture for $30 \mathrm{~min}$ at the same temperature, a solution of monoacetate 16 (2.79 g, $15.1 \mathrm{mmol})$ in $\mathrm{CH}_{2} \mathrm{Cl}_{2}(202$ $\mathrm{mL}$ ) was dropwised over $3.5 \mathrm{~h}$. After stirring for $30 \mathrm{~min}$, to the reaction mixture was added brine and then warmed to room temperature. After stirring for $30 \mathrm{~min}$, the mixture was added $\mathrm{MgSO}_{4}(1.06 \mathrm{~g})$ and Celite $(133 \mathrm{mg})$ and after stirring for $15 \mathrm{~min}$, the mixture was passed through a pad of Celite and then concentrated in vacuo. The residue was purified with flash column chromatography on silica gel (hexane/EtOAc $=1: 2$ to $0: 1)$ to give epoxyalcohol 5 (2.97 g, 98\% yield, >95\% ee) as a colorless oil: $R_{\mathrm{f}} 0.30$ (hexane/EtOAc $\left.=1: 2\right) ;[\alpha]_{\mathrm{D}}^{25}+19.9(c 1.68$, $\mathrm{CHCl}_{3}$ ); IR (neat) $\nu_{\max } 3444,2933,1739,1672,1239 \mathrm{~cm}^{-1} ;{ }^{1} \mathrm{H}$ NMR $\left(\mathrm{CDCl}_{3}, 400 \mathrm{MHz}\right) \delta 5.78(1 \mathrm{H}, \mathrm{m}), 5.63(1 \mathrm{H}, \mathrm{m}), 4.52(2 \mathrm{H}, \mathrm{d}$, $J=6.2 \mathrm{~Hz}), 3.89$ (1H, ddd, $J=2.6,5.2,12.4 \mathrm{~Hz}), 3.64(1 \mathrm{H}, \mathrm{m})$, $2.97(1 \mathrm{H}, \mathrm{dt}, J=2.3,5.8 \mathrm{~Hz}), 2.92(1 \mathrm{H}, \mathrm{dt}, J=4.0,2.6 \mathrm{~Hz}), 2.30-$ $2.15(2 \mathrm{H}, \mathrm{m}), 2.06$ (3H, s), 1.72-1.65 (2H, m), $1.61(1 \mathrm{H}, \mathrm{brs}) ;{ }^{13} \mathrm{C}$ NMR $\left(\mathrm{CDCl}_{3}, 100 \mathrm{MHz}\right) \delta 170.8(\mathrm{C}), 134.6(\mathrm{CH}), 124.8(\mathrm{CH}), 64.9$ $\left(\mathrm{CH}_{2}\right), 61.6\left(\mathrm{CH}_{2}\right), 58.5(\mathrm{CH}), 55.3(\mathrm{CH}), 30.8\left(\mathrm{CH}_{2}\right), 28.6\left(\mathrm{CH}_{2}\right)$, $20.9\left(\mathrm{CH}_{3}\right)$; MS (ESI-TOF) $\mathrm{m} / z 223[\mathrm{M}+\mathrm{Na}]^{+}$(100); HRMS (ESITOF) $m / z[\mathrm{M}+\mathrm{Na}]^{+}$calcd for $\mathrm{C}_{10} \mathrm{H}_{16} \mathrm{O}_{4} \mathrm{Na} 223.0946$, found 223.0939; anal. calcd for $\mathrm{C}_{10} \mathrm{H}_{16} \mathrm{O}_{4}$ : C, 59.98; $\mathrm{H}, 8.05$. Found: $\mathrm{C}$, 59.83; H, 8.14.

Determination of optical purity of synthetic (+)-epoxyalcohol 5. Before comparison between synthetic (+)-epoxyalcohol 5 and synthetic racemic epoxyalcohol rac-5 with Chirabite-AR, we examined the effect of differing amounts of Chirabite-AR regarding rac-5, to determine sufficient signal separations between (+)- and (-)-5. Consequently, a mixture of rac-5 with $100 \mathrm{~mol} \%$ of Chirabite-AR was measured sequentially by 400 $\mathrm{MHz}{ }^{1} \mathrm{H} \mathrm{NMR}$ at room temperature in $\mathrm{CDCl}_{3}$, the methine proton signal separations were observed between 3.92 to $3.86 \mathrm{ppm}$, and good enantiomeric discrimination was achieved for $(+)$ - and (-)-5. NMR analysis of (+)-epoxyalcohol 5 under the same conditions as used to obtain the results indicated that no signal derived from (-)-5 was observed. Therefore, the optical purity of synthetic $(+)-5$ was determined as $>95 \%$ ee.

(E)-5-((2R,3R)-3-((Methoxymethoxy)methyl)oxiran-2-yl)pent2-en-1-ol (6). To a stirred solution of epoxyalcohol 5 (2.97 g, 12.8 $\mathrm{mmol})$ in $\mathrm{CH}_{2} \mathrm{Cl}_{2}(74.0 \mathrm{~mL})$ were added DIPEA $(25.8 \mathrm{~mL}, 148$ mmol) and MOMCl $(3.37 \mathrm{~mL}, 44.4 \mathrm{mmol})$ at $0{ }^{\circ} \mathrm{C}$, and then refluxed. After stirring for $3 \mathrm{~h}$, the mixture was cooled to room temperature, and then quenched with saturated aqueous $\mathrm{NaHCO}_{3}$ solution, diluted with $\mathrm{Et}_{2} \mathrm{O}$, washed with $1.0 \mathrm{M} \mathrm{HCl}$ aq., $\mathrm{H}_{2} \mathrm{O}$, and brine, dried over anhydrous $\mathrm{MgSO}_{4}$ and $\mathrm{Na}_{2} \mathrm{SO}_{4}$, and then concentrated in vacuo to give a crude MOM ether which was used for the next step without further purification.

To a stirred solution of the crude MOM ether in methanol (46.3 $\mathrm{mL})$ was added $\mathrm{K}_{2} \mathrm{CO}_{3}(9.61 \mathrm{~g}, 69.5 \mathrm{mmol})$ at room temperature. After stirring the mixture for $30 \mathrm{~min}$, the mixture was diluted with $\mathrm{Et}_{2} \mathrm{O}$, and then was passed through a pad of silica gel and then concentrated in vacuo. The residue was 
purified with flash column chromatography on silica gel (hexane/EtOAc $=1: 2$ ) to give allylic alcohol 6 ( $2.65 \mathrm{~g}, 88 \%$ yield for 2 steps) as a colorless oil: $R_{\mathrm{f}} 0.60$ (hexane/EtOAc $=1: 2$ ); $[\alpha]_{\mathrm{D}}^{25}+16.5\left(c \quad 0.83, \mathrm{CHCl}_{3}\right)$; IR (neat) $\nu_{\max } 3433,2991,2933$, $2863 \mathrm{~cm}^{-1} ;{ }^{1} \mathrm{H} \mathrm{N} / \mathrm{MR}\left(\mathrm{CDCl}_{3}, 400 \mathrm{MHz}\right) \delta 5.72-5.69(2 \mathrm{H}, \mathrm{m}), 4.66$ $(1 \mathrm{H}, \mathrm{d}, J=7.5 \mathrm{~Hz}), 4.64(1 \mathrm{H}, \mathrm{d}, J=7.5 \mathrm{~Hz}), 4.12-4.08(2 \mathrm{H}, \mathrm{m})$, $3.70(1 \mathrm{H}, \mathrm{dd}, J=3.8,11.6 \mathrm{~Hz}), 3.57(1 \mathrm{H}, \mathrm{dd}, J=5.4,11.6 \mathrm{~Hz})$, $3.38(3 \mathrm{H}, \mathrm{s}), 2.94(1 \mathrm{H}, \mathrm{ddd}, J=2.3,3.8,5.8 \mathrm{~Hz}), 2.86(1 \mathrm{H}, \mathrm{dt}, J=$ 2.1, $5.8 \mathrm{~Hz}), 2.30-2.18$ (2H, m), 1.71-1.67 (2H, m), 1.52 (1H, brs); ${ }^{13} \mathrm{C} \mathrm{NMR}\left(\mathrm{CDCl}_{3}, 100 \mathrm{MHz}\right) \delta 131.4(\mathrm{CH}), 130.0(\mathrm{CH}), 96.5\left(\mathrm{CH}_{2}\right)$, $67.8\left(\mathrm{CH}_{2}\right), 63.4\left(\mathrm{CH}_{2}\right), 56.7(\mathrm{CH}), 55.9(\mathrm{CH}), 55.3\left(\mathrm{CH}_{3}\right), 31.1$ $\left(\mathrm{CH}_{2}\right), 28.6\left(\mathrm{CH}_{2}\right)$; MS (ESI-TOF) $m / z 225[\mathrm{M}+\mathrm{Na}]^{+}(100)$; HRMS (ESI-TOF) $m / z[\mathrm{M}+\mathrm{Na}]^{+}$calcd for $\mathrm{C}_{10} \mathrm{H}_{18} \mathrm{O}_{4} \mathrm{Na} 225.1103$, found 225.1104; anal. calcd for $\mathrm{C}_{10} \mathrm{H}_{18} \mathrm{O}_{4}$ : C, 59.39; H, 8.97. Found: C, $59.21 ; \mathrm{H}, 8.97$.

Ethyl 3-((2R,3R)-3-(2-((2R,3R)-3-((methoxymethoxy)methyl) oxiran-2-yl)ethyl)oxiran-2-yl)propanoate (7). To a stirred solution of epoxyalcohol 6 (1.69 g, $7.74 \mathrm{mmol})$ in $\mathrm{CH}_{2} \mathrm{Cl}_{2}(155 \mathrm{~mL})$ were added $\mathrm{NaHCO}_{3}(2.60 \mathrm{~g}, 30.9 \mathrm{mmol})$ and Dess-Martin periodinane $(6.57 \mathrm{~g}, 15.5 \mathrm{mmol})$ at room temperature. After stirring for $40 \mathrm{~min}$, the mixture was added $\mathrm{Ph}_{3} \mathrm{PCHCO}_{2} \mathrm{Et}$ (4.04 $\mathrm{g}, 11.6 \mathrm{mmol})$ at same temperature. After stirring for $15 \mathrm{~min}$, the mixture was quenched with saturated aqueous $\mathrm{NaHCO}_{3}$ solution, diluted with $\mathrm{Et}_{2} \mathrm{O}$, washed with $10 \%$ aqueous $\mathrm{Na}_{2} \mathrm{SO}_{3}$ solution, $\mathrm{H}_{2} \mathrm{O}$ and brine, dried over anhydrous $\mathrm{MgSO}_{4}$ and $\mathrm{Na}_{2} \mathrm{SO}_{4}$, and then concentrated in vacuo to give a crude $\alpha, \beta$ unsaturated ester which was used for the next step without further purification.

After a suspension of $5 \% \mathrm{Rh} / \mathrm{Al}_{2} \mathrm{O}_{3}(308 \mathrm{mg})$ in THF $(268 \mathrm{~mL})$ was stirred under hydrogen atmosphere at room temperature for $30 \mathrm{~min}$, a solution of above crude $\alpha, \beta$-unsaturated ester in THF $(40.0 \mathrm{~mL})$ was added to the stirred suspension. After stirring for $2 \mathrm{~h}$, argon was blown into the reaction mixture in order to remove hydrogen and then diluted with $\mathrm{Et}_{2} \mathrm{O}$, filtered through silica gel pad, and concentrated in vacuo. The residue was purified with flash column chromatography on silica gel (hexane/EtOAc $=2: 1$ ) to give bisepoxyester 7 (1.15 $\mathrm{g}, 51 \%$ yield for 2 steps) as a colorless oil: $R_{\mathrm{f}} 0.30$ (hexane/EtOAc $=1: 1$ ); $[\alpha]_{\mathrm{D}}^{25}+39.5\left(c 0.28, \mathrm{CHCl}_{3}\right)$; IR (neat) $\nu_{\max } 2981,2935,1733$, $1640 \mathrm{~cm}^{-1} ;{ }^{1} \mathrm{H} \mathrm{NMR}\left(\mathrm{CDCl}_{3}, 400 \mathrm{MHz}\right) \delta 4.66(1 \mathrm{H}, \mathrm{d}, J=7.6 \mathrm{~Hz})$, $4.64(1 \mathrm{H}, \mathrm{d}, J=7.6 \mathrm{~Hz}), 4.14(2 \mathrm{H}, \mathrm{q}, J=7.2 \mathrm{~Hz}), 3.73(1 \mathrm{H}, \mathrm{dd}, J=$ $3.5,11.7 \mathrm{~Hz}), 3.56(1 \mathrm{H}, \mathrm{dd}, J=5.5,11.7 \mathrm{~Hz}), 3.37(3 \mathrm{H}, \mathrm{s}), 2.96$ (1H, ddd, $J=2.3,3.5,5.6 \mathrm{~Hz}), 2.90(1 \mathrm{H}, \mathrm{m}), 2.80-2.74(2 \mathrm{H}, \mathrm{m})$, 2.47-2.41 (2H, m), $1.96(1 \mathrm{H}, \mathrm{m}), 1.82-1.60(5 \mathrm{H}, \mathrm{m}), 1.26(3 \mathrm{H}, \mathrm{t}, J$ $=7.2 \mathrm{~Hz}) ;{ }^{13} \mathrm{C} \mathrm{NMR}\left(\mathrm{CDCl}_{3}, 100 \mathrm{MHz}\right) \delta 172.8(\mathrm{C}), 96.6\left(\mathrm{CH}_{2}\right)$, $67.7\left(\mathrm{CH}_{2}\right), 60.5\left(\mathrm{CH}_{2}\right), 58.0(\mathrm{CH}), 57.5(\mathrm{CH}), 56.7(\mathrm{CH}), 55.5$ $(\mathrm{CH}), 55.3\left(\mathrm{CH}_{3}\right), 30.4\left(\mathrm{CH}_{2}\right), 28.2\left(\mathrm{CH}_{2}\right), 28.0\left(\mathrm{CH}_{2}\right), 27.1\left(\mathrm{CH}_{2}\right)$, $14.2\left(\mathrm{CH}_{3}\right)$; MS (ESI-TOF) $m / z 311[\mathrm{M}+\mathrm{Na}]^{+}(100)$; HRMS (ESITOF) $m / z[\mathrm{M}+\mathrm{Na}]^{+}$calcd for $\mathrm{C}_{14} \mathrm{H}_{24} \mathrm{O}_{6} \mathrm{Na} 311.1471$, found 311.1459; anal. calcd for $\mathrm{C}_{14} \mathrm{H}_{24} \mathrm{O}_{6}$ : C, 58.32; H, 8.39. Found: $\mathrm{C}$, 58.16; H, 8.29.

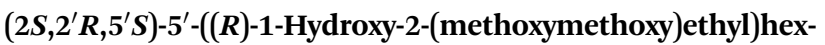
ahydro-[2,2'-bifuran]-5(2H)-one (8). To a stirred solution of bisepoxyester $7(35.1 \mathrm{mg}, 0.122 \mathrm{mmol})$ in $\mathrm{CH}_{2} \mathrm{Cl}_{2}(0.700 \mathrm{~mL})$ was added a solution of $( \pm)$-10-camphorsulfonic acid $(5.7 \mathrm{mg}$, $0.0244 \mathrm{mmol})$ in $\mathrm{CH}_{2} \mathrm{Cl}_{2}(1.70 \mathrm{~mL})$ and $\mathrm{H}_{2} \mathrm{O}(0.0022 \mathrm{~mL}, 0.122$ $\mathrm{mmol}$ ) at room temperature. After stirring for $2 \mathrm{~h}$, the reaction mixture was concentrated and then purified with flash column chromatography on silica gel (hexane/EtOAc $=1: 10$ ) to give tetrahydrofuran 8 (28.9 mg, 91\% yield) as a colorless oil: $R_{\mathrm{f}} 0.30$ (hexane/EtOAc $=1: 4) ;[\alpha]_{\mathrm{D}}^{25}+14.4\left(c 0.83, \mathrm{CHCl}_{3}\right)$; IR (neat) $\nu_{\max }$ 3434, 2948, 2889, 1767, $1644 \mathrm{~cm}^{-1} ;{ }^{1} \mathrm{H} \mathrm{NMR}\left(\mathrm{CDCl}_{3}, 400 \mathrm{MHz}\right)$ $\delta 4.67(1 \mathrm{H}, \mathrm{d}, J=7.0 \mathrm{~Hz}), 4.66(1 \mathrm{H}, \mathrm{d}, J=7.0 \mathrm{~Hz}), 4.44(1 \mathrm{H}, \mathrm{m})$, $3.99(1 \mathrm{H}, \mathrm{m}), 3.90(1 \mathrm{H}, \mathrm{m}), 3.75-3.67(2 \mathrm{H}, \mathrm{m}), 3.57$ (1H, m), 3.39 $(3 \mathrm{H}, \mathrm{s}), 2.69(1 \mathrm{H}, \mathrm{brd}, J=4.0 \mathrm{~Hz}), 2.60-2.45(2 \mathrm{H}, \mathrm{m}), 2.30(1 \mathrm{H}$, $\mathrm{m}), 2.15-1.92(4 \mathrm{H}, \mathrm{m}), 1.80(1 \mathrm{H}, \mathrm{m}) ;{ }^{13} \mathrm{C} \mathrm{NMR}\left(\mathrm{CDCl}_{3}, 100 \mathrm{MHz}\right)$ $\delta 177.0(\mathrm{C}), 97.2\left(\mathrm{CH}_{2}\right), 81.2(\mathrm{CH}), 80.2(\mathrm{CH}), 79.9(\mathrm{CH}), 72.3$ $(\mathrm{CH}), 70.4\left(\mathrm{CH}_{2}\right), 55.5\left(\mathrm{CH}_{3}\right), 28.1\left(\mathrm{CH}_{2}\right), 27.3\left(\mathrm{CH}_{2}\right), 26.7\left(\mathrm{CH}_{2}\right)$, $23.9\left(\mathrm{CH}_{2}\right)$; MS (ESI-TOF) $m / z 283[\mathrm{M}+\mathrm{Na}]^{+}$(100); HRMS (ESITOF) $m / z[\mathrm{M}+\mathrm{Na}]^{+}$calcd for $\mathrm{C}_{12} \mathrm{H}_{20} \mathrm{O}_{6} \mathrm{Na} 283.1158$, found 283.1150; anal. calcd for $\mathrm{C}_{12} \mathrm{H}_{20} \mathrm{O}_{6}$ : C, 55.37; H, 7.75. Found: $\mathrm{C}$, $55.23 ; \mathrm{H}, 7.81$.

(R)-2-Hydroxy-2-((2R,2' $S, 5 S)-5^{\prime}$-oxooctahydro-[2,2'-bifuran]-5yl)ethyl 3,5-dinitrobenzoate (9). To a stirred solution of tetrahydrofuran 8 (20.0 mg, $0.0769 \mathrm{mmol})$ in $\mathrm{CH}_{2} \mathrm{Cl}_{2}(2.56 \mathrm{~mL})$ were added WSC (88.5 mg, $0.462 \mathrm{mmol})$, DMAP (2.8 $\mathrm{mg}$. $0.0231 \mathrm{~mol}$ ), and 3,5-dinitrobenzoic acid $(48.9 \mathrm{mg}, 0.231 \mathrm{mmol}$ ) at room temperature. After stirring for $15 \mathrm{~min}$, the mixture was quenched with saturated aqueous $\mathrm{NaHCO}_{3}$ solution, diluted with $\mathrm{Et}_{2} \mathrm{O}$, washed with $\mathrm{H}_{2} \mathrm{O}$, and brine, dried over anhydrous $\mathrm{MgSO}_{4}$ and $\mathrm{Na}_{2} \mathrm{SO}_{4}$, and then concentrated in vacuo to give a crude dinitrobenzoate which was used for the next step without further purification.

To a solution of above crude dinitrobenzoate in $\mathrm{CH}_{2} \mathrm{Cl}_{2}(2.56$ $\mathrm{mL})$ were added $\mathrm{Me}_{2} \mathrm{~S}(0.256 \mathrm{~mL}, 3.50 \mathrm{mmol})$ and $\mathrm{BF}_{3} \cdot \mathrm{OEt}_{2}$ $(0.0285 \mathrm{~mL}, 0.230 \mathrm{mmol})$ at $-30{ }^{\circ} \mathrm{C}$. After stirring for $1.5 \mathrm{~h}$, the reaction mixture was quenched with $\mathrm{Et}_{3} \mathrm{~N}(0.0107 \mathrm{~mL}, 0.0769$ $\mathrm{mmol}$ ) and warmed to room temperature. The mixture was diluted with $\mathrm{Et}_{2} \mathrm{O}$, washed with saturated aqueous $\mathrm{NaHCO}_{3}$ solution, $\mathrm{H}_{2} \mathrm{O}$, and brine, dried over anhydrous $\mathrm{MgSO}_{4}$ and $\mathrm{Na}_{2} \mathrm{SO}_{4}$, and then concentrated in vacuo. The residue was purified with flash column chromatography on silica gel (hexane/EtOAc $=1: 2$ ) to give dinitrobenzoate 9 (25.5 mg, 81\% yield for two steps) as a white needle: ${ }^{1} \mathrm{H} \mathrm{NMR}\left(\mathrm{CDCl}_{3}, 400 \mathrm{MHz}\right)$ $\delta 9.24(1 \mathrm{H}, \mathrm{m}), 9.19-9.15(2 \mathrm{H}, \mathrm{m}), 4.63(1 \mathrm{H}, \mathrm{dd}, J=3.0,11.6 \mathrm{~Hz})$, 4.57-4.43 (2H, m), 4.20-3.92 (3H, m), 2.60-2.53 (2H, m), 2.40$2.22(2 \mathrm{H}, \mathrm{m}), 2.18-1.92(4 \mathrm{H}, \mathrm{m}), 1.52$ (1H, bs); ESI-MS m/z 433 [M $+\mathrm{Na}]^{+}(100)$ ); HR-ESI-MS $m / z 433.0858$ (calcd for $\mathrm{C}_{17} \mathrm{H}_{18} \mathrm{~N}_{2} \mathrm{O}_{10} \mathrm{Na}$, 433.0859).

$(R)-1-((2 S, 5 R)-5-((S)-1-H y d r o x y t r i d e c y l) t e t r a h y d r o f u r a n-2-y l)$ ethane-1,2-diol (10). To a stirred solution of tetrahydrofuran 8 (794 $\mathrm{mg}, 3.05 \mathrm{mmol})$ in $\mathrm{CH}_{2} \mathrm{Cl}_{2}(61.0 \mathrm{~mL})$ was added DIBAH (1.02 M solution in hexane, $8.97 \mathrm{~mL}, 9.15 \mathrm{mmol}$ ) at $-78^{\circ} \mathrm{C}$. After stirring for $30 \mathrm{~min}$, the reaction mixture was added $\mathrm{Na}_{2} \mathrm{SO}_{4}$ $\cdot 10 \mathrm{H}_{2} \mathrm{O}(50.0 \mathrm{mg})$ slowly, diluted with $\mathrm{CH}_{2} \mathrm{Cl}_{2}$, and then warmed to room temperature. After stirring for $24 \mathrm{~h}$, the mixture was added $\mathrm{MgSO}_{4}$. After stirring for $15 \mathrm{~min}$, the resulting mixture passed through a pad of $\mathrm{Na}_{2} \mathrm{SO}_{4}$ and then concentrated in vacuo to give a crude hemiacetal which was used for the next step without further purification.

To a stirred suspension of nonyltriphenylphosphonium bromide $(8.00 \mathrm{~g}, 17.0 \mathrm{mmol})$ in THF $(41.0 \mathrm{~mL})$ was added BuLi (1.64 M solution in hexane, $9.30 \mathrm{~mL}, 15.3 \mathrm{mmol}$ ) dropwise at $0{ }^{\circ} \mathrm{C}$ and the mixture was stirred for $1.5 \mathrm{~h}$ at same temperature. 
A solution of the above crude hemiacetal in THF $(20.0 \mathrm{~mL})$ was then added to the mixture at $0{ }^{\circ} \mathrm{C}$ and then warmed to room temperature. After stirring for $2 \mathrm{~h}$, the reaction mixture was quenched with saturated aqueous $\mathrm{NH}_{4} \mathrm{Cl}$ solution, diluted with EtOAc, washed with $\mathrm{H}_{2} \mathrm{O}$ and brine, dried over anhydrous $\mathrm{Na}_{2} \mathrm{SO}_{4}$, and then concentrated in vacuo. The residue was passed through a pad of silica gel (hexane/EtOAc $=1: 1$ ) and then concentrated in vacuo to give a crude diol which was used for the next step without further purification.

To a solution of above crude diol in $\mathrm{MeOH}(117 \mathrm{~mL})$ was added $\mathrm{Pd} / \mathrm{C}$ (5\%, $117 \mathrm{mg})$, and then was stirred under $\mathrm{H}_{2}$ atmosphere. After stirring for $1 \mathrm{~h}$, the reaction mixture was diluted with $\mathrm{Et}_{2} \mathrm{O}$ and passed through a pad of silica gel and then concentrated in vacuo. The residue was passed through a pad of silica gel (hexane/EtOAc $=1: 2$ ) and then concentrated in vacuo. The residue was passed through a pad of silica gel (toluene/EtOAc $=2: 1$ ) and then concentrated in vacuo to give a crude diol which was used for the next step without further purification.

To a solution of above crude diol in $\mathrm{CH}_{2} \mathrm{Cl}_{2}(22.1 \mathrm{~mL})$ were added $\mathrm{Me}_{2} \mathrm{~S}(7.37 \mathrm{~mL}, 99.6 \mathrm{mmol})$ and $\mathrm{BF}_{3} \cdot \mathrm{OEt}_{2}(1.36 \mathrm{~mL}, 11.0$ $\mathrm{mmol}$ ) at $-30{ }^{\circ} \mathrm{C}$. After stirring for $30 \mathrm{~min}$, the reaction mixture was quenched with $\mathrm{Et}_{3} \mathrm{~N}$ (3.08 $\left.\mathrm{mL}, 22.1 \mathrm{mmol}\right)$ and warmed to room temperature. The mixture was diluted with $\mathrm{Et}_{2} \mathrm{O}$, washed with saturated aqueous $\mathrm{NaHCO}_{3}$ solution, $\mathrm{H}_{2} \mathrm{O}$, and brine, dried over anhydrous $\mathrm{MgSO}_{4}$ and $\mathrm{Na}_{2} \mathrm{SO}_{4}$, and then concentrated in vacuo. The residue was purified with flash column chromatography on silica gel (hexane/EtOAc $=1: 4$ to $0: 1$ ) to give triol 10 (575 mg, 57\% yield for four steps) as a white plate: $R_{\mathrm{f}} 0.30\left(\mathrm{CHCl}_{3} / \mathrm{MeOH}=15: 1\right) ; \mathrm{mp} 76-77^{\circ} \mathrm{C} ;[\alpha]_{\mathrm{D}}^{25}+2.7(c 1.04$, $\mathrm{CHCl}_{3}$ ); IR (KBr) $\nu_{\max } 3393,3283,2925,2850,1153 \mathrm{~cm}^{-1} ;{ }^{1} \mathrm{H}$ NMR $\left(\mathrm{CDCl}_{3}, 400 \mathrm{MHz}\right) \delta 3.99(1 \mathrm{H}, \mathrm{dt}, J=4.1,7.1 \mathrm{~Hz}), 3.89(1 \mathrm{H}$, $\mathrm{m}), 3.87-3.81(2 \mathrm{H}, \mathrm{m}), 3.71(1 \mathrm{H}, \mathrm{dd}, J=3.9,11.2 \mathrm{~Hz}), 3.61(1 \mathrm{H}$, $\mathrm{dd}, J=6.4,11.2 \mathrm{~Hz}), 2.00-1.87$ (3H, m), $1.82(1 \mathrm{H}, \mathrm{m}), 1.54-1.20$ $(22 \mathrm{H}, \mathrm{m}), 0.88(3 \mathrm{H}, \mathrm{t}, J=6.7 \mathrm{~Hz}) ;{ }^{13} \mathrm{C} \mathrm{NMR}\left(\mathrm{CDCl}_{3}, 100 \mathrm{MHz}\right)$ $\delta 82.4(\mathrm{CH}), 80.2(\mathrm{CH}), 73.4(\mathrm{CH}), 72.2(\mathrm{CH}), 63.9\left(\mathrm{CH}_{2}\right), 33.2$ $\left(\mathrm{CH}_{2}\right), 31.9\left(\mathrm{CH}_{2}\right), 29.7\left(\mathrm{CH}_{2}\right) \times 2,29.64\left(\mathrm{CH}_{2}\right), 29.63\left(\mathrm{CH}_{2}\right)$, $29.61\left(\mathrm{CH}_{2}\right), 29.56\left(\mathrm{CH}_{2}\right), 29.3\left(\mathrm{CH}_{2}\right), 26.3\left(\mathrm{CH}_{2}\right), 26.0\left(\mathrm{CH}_{2}\right), 24.0$ $\left(\mathrm{CH}_{2}\right), 22.7\left(\mathrm{CH}_{2}\right), 14.1\left(\mathrm{CH}_{3}\right)$; MS (ESI-TOF) $\mathrm{m} / \mathrm{z} 353[\mathrm{M}+\mathrm{Na}]^{+}$ (100); HRMS (ESI-TOF) $m / z$ [M $+\mathrm{Na}]^{+}$calcd for $\mathrm{C}_{19} \mathrm{H}_{38} \mathrm{O}_{4} \mathrm{Na}$ 353.2668, found 353.2672; anal. calcd for $\mathrm{C}_{19} \mathrm{H}_{38} \mathrm{O}_{4}$ : C, 69.05; $\mathrm{H}$, 11.59. Found: C, 69.28; H, 11.54 .

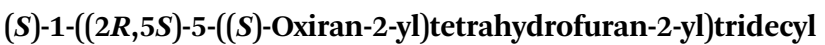
acetate (11). To a stirred solution of triol $10(102 \mathrm{mg}, 0.309$ $\mathrm{mmol})$ in 2,2-dimethoxypropane $(10.3 \mathrm{~mL})$ was added $p \mathrm{TsOH} \cdot \mathrm{H}_{2} \mathrm{O}(5.9 \mathrm{mg}, 0.0310 \mathrm{mmol})$ at room temperature. After stirring for $4 \mathrm{~h}$, the mixture was diluted with $\mathrm{Et}_{2} \mathrm{O}$, washed with $\mathrm{H}_{2} \mathrm{O}$ and brine, dried over anhydrous $\mathrm{MgSO}_{4}$ and $\mathrm{Na}_{2} \mathrm{SO}_{4}$, and then concentrated in vacuo to give a crude acetonide which was used for the next step without further purification.

Acetic anhydride $(3.10 \mathrm{~mL}, 32.8 \mathrm{mmol})$ was added to a stirred solution of the above crude acetonide in pyridine $(3.10 \mathrm{~mL}, 38.5$ $\mathrm{mmol}$ ) at room temperature. After stirring for $12 \mathrm{~h}$, the mixture was concentrated in vacuo to give a crude acetate which was used for the next step without further purification.

To the above crude acetate was added $80 \% \mathrm{AcOH}$ aq. (3.10 $\mathrm{mL}$ ) at room temperature. The mixture was warmed to $50{ }^{\circ} \mathrm{C}$ and after $40 \mathrm{~min}$ recooled to room temperature. The mixture was diluted with EtOAc, washed with saturated aqueous $\mathrm{NaHCO}_{3}$ solution $\mathrm{H}_{2} \mathrm{O}$ and brine, dried over anhydrous $\mathrm{MgSO}_{4}$ and $\mathrm{Na}_{2} \mathrm{SO}_{4}$, and then concentrated in vacuo to give a crude diol which was used for the next step without further purification.

To a stirred solution of the above crude diol in $\mathrm{CH}_{2} \mathrm{Cl}_{2}(0.618$ $\mathrm{mL})$ were added $\mathrm{Et}_{3} \mathrm{~N}(0.258 \mathrm{~mL}, 1.85 \mathrm{mmol})$, TBSCl $(140 \mathrm{mg}$, $0.929 \mathrm{mmol})$, and DMAP $(3.8 \mathrm{mg}, 0.0311 \mathrm{mmol})$ at $0{ }^{\circ} \mathrm{C}$ and then warmed to room temperature. After stirring for $3.5 \mathrm{~h}$, the mixture was quenched with saturated aqueous $\mathrm{NaHCO}_{3}$ solution, diluted with $\mathrm{Et}_{2} \mathrm{O}$, washed with $\mathrm{H}_{2} \mathrm{O}$, and brine, dried over anhydrous $\mathrm{MgSO}_{4}$ and $\mathrm{Na}_{2} \mathrm{SO}_{4}$, and then concentrated in vacuo to give a crude TBS ether which was used for the next step without further purification.

To a stirred solution of the above crude TBS ether in $\mathrm{CH}_{2} \mathrm{Cl}_{2}$ $(3.10 \mathrm{~mL})$ were added $\mathrm{Et}_{3} \mathrm{~N}(0.172 \mathrm{~mL}, 1.23 \mathrm{mmol})$ and $\mathrm{MsCl}$ $(0.048 \mathrm{~mL}, 0.620 \mathrm{mmol})$ at $0{ }^{\circ} \mathrm{C}$ and then warmed to room temperature. After stirring for $45 \mathrm{~min}$, the mixture was quenched with saturated aqueous $\mathrm{NaHCO}_{3}$ solution, diluted with $\mathrm{Et}_{2} \mathrm{O}$, washed with $\mathrm{H}_{2} \mathrm{O}$, and brine, dried over anhydrous $\mathrm{MgSO}_{4}$ and $\mathrm{Na}_{2} \mathrm{SO}_{4}$, and then concentrated in vacuo to give a crude mesylate which was used for the next step without further purification.

To a stirred solution of the above crude mesylate in THF $(3.10 \mathrm{~mL})$ were added TBAF $(1.00 \mathrm{M}$ solution in THF, $0.773 \mathrm{~mL}$, $0.773 \mathrm{mmol}$ ) at room temperature. After stirring for $1 \mathrm{~h}$, the mixture was warmed to $50{ }^{\circ} \mathrm{C}$ and stirred for $12 \mathrm{~h}$. The mixture was diluted with $\mathrm{Et}_{2} \mathrm{O}$, washed with $\mathrm{H}_{2} \mathrm{O}$, and brine, dried over anhydrous $\mathrm{MgSO}_{4}$ and $\mathrm{Na}_{2} \mathrm{SO}_{4}$, and then concentrated in vacuo. The residue was purified with flash column chromatography on silica gel (hexane/EtOAc $=6: 1)$ to give epoxide $11(95.3 \mathrm{mg}$, $87 \%$ yield for six steps) as a white waxy solid: $R_{\mathrm{f}} 0.60$ (hexane/ EtOAc = $1: 1) ; \operatorname{mp~} 31-32{ }^{\circ} \mathrm{C} ;[\alpha]_{\mathrm{D}}^{25}-10.5\left(c \quad 0.19, \mathrm{CHCl}_{3}\right)$; IR $(\mathrm{KBr}) \nu_{\max } 2925,2854,1741,1466,1370,1239 \mathrm{~cm}^{-1} ;{ }^{1} \mathrm{H}$ NMR $\left(\mathrm{CDCl}_{3}, 400 \mathrm{MHz}\right) \delta 4.98(1 \mathrm{H}, \mathrm{ddd}, J=4.4,4.7,8.8 \mathrm{~Hz}), 3.93(1 \mathrm{H}$, $\mathrm{m}), 3.83(1 \mathrm{H}, \mathrm{m}), 2.94(1 \mathrm{H}, \mathrm{ddd}, J=2.6,4.3,7.1 \mathrm{~Hz}), 2.73(1 \mathrm{H}$, $\mathrm{dd}, J=4.3,5.2 \mathrm{~Hz}), 2.65(1 \mathrm{H}, \mathrm{dd}, J=2.6,5.2 \mathrm{~Hz}), 2.07(3 \mathrm{H}, \mathrm{s})$, 2.05-1.76 (4H, m), 1.37-1.15 (22H, m), $0.88(3 \mathrm{H}, \mathrm{t}, J=7.0 \mathrm{~Hz})$; ${ }^{13} \mathrm{C} \mathrm{NMR}\left(\mathrm{CDCl}_{3}, 100 \mathrm{MHz}\right) \delta 170.7(\mathrm{C}), 80.8(\mathrm{CH}), 78.7(\mathrm{CH})$, $74.4(\mathrm{CH}), 53.8(\mathrm{CH}), 44.0\left(\mathrm{CH}_{2}\right), 31.9\left(\mathrm{CH}_{2}\right), 30.9\left(\mathrm{CH}_{2}\right), 29.6$ $\left(\mathrm{CH}_{2}\right), 29.6\left(\mathrm{CH}_{2}\right) \times 2,29.6\left(\mathrm{CH}_{2}\right), 29.5\left(\mathrm{CH}_{2}\right) \times 2,29.3\left(\mathrm{CH}_{2}\right)$, $28.1\left(\mathrm{CH}_{2}\right), 26.8\left(\mathrm{CH}_{2}\right), 25.3\left(\mathrm{CH}_{2}\right), 22.7\left(\mathrm{CH}_{2}\right), 21.2\left(\mathrm{CH}_{3}\right), 14.1$ $\left(\mathrm{CH}_{3}\right)$; MS (ESI-TOF) $\mathrm{m} / z 377[\mathrm{M}+\mathrm{Na}]^{+}$(100); HRMS (ESI-TOF) $m / z[\mathrm{M}+\mathrm{Na}]^{+}$calcd for $\mathrm{C}_{21} \mathrm{H}_{38} \mathrm{O}_{4} \mathrm{Na} 377.2668$, found 377.2664; anal. calcd for $\mathrm{C}_{21} \mathrm{H}_{38} \mathrm{O}_{4}$ : C, 71.14; $\mathrm{H}, 10.80$. Found: $\mathrm{C}, 70.97 ; \mathrm{H}$, 10.95.

\section{$(S)-1-((2 R, 5 S)-5-((S)-1-H y d r o x y t r i d e c-12-e n-1-y l)$}

tetrahydrofuran-2-yl)tridecyl acetate (12). At $-60{ }^{\circ} \mathrm{C}$, undec-10enylmagnesium bromide $(0.40 \mathrm{M}$ solution in THF, $1.40 \mathrm{~mL}$, $0.560 \mathrm{mmol}$ ) was added dropwise to a suspension of CuI $(53.8 \mathrm{mg}, 0.283 \mathrm{mmol})$ in THF $(0.40 \mathrm{~mL})$. The mixture was warmed to $-30{ }^{\circ} \mathrm{C}$ and after $20 \mathrm{~min}$ recooled to $-60{ }^{\circ} \mathrm{C}$ whereupon a solution of epoxide $11(50.1 \mathrm{mg}, 0.141 \mathrm{mmol})$ in THF $(1.00 \mathrm{~mL})$ was added dropwise. The mixture was allowed to warm to $-20{ }^{\circ} \mathrm{C}$ over $4 \mathrm{~h}$. Saturated aqueous $\mathrm{NH}_{4} \mathrm{Cl}$ solution/ $\mathrm{NH}_{3}(8: 1,1.40 \mathrm{~mL})$ was added to the reaction mixture. The mixture was diluted with $\mathrm{Et}_{2} \mathrm{O}$, washed with saturated aqueous 
$\mathrm{NH}_{4} \mathrm{Cl}$ solution, $\mathrm{H}_{2} \mathrm{O}$, and brine, dried over anhydrous $\mathrm{MgSO}_{4}$ and $\mathrm{Na}_{2} \mathrm{SO}_{4}$, and then concentrated in vacuo. The residue was purified with flash column chromatography on silica gel (hexane/EtOAc $=7: 1)$ to give alcohol $12(56.8 \mathrm{mg}, 79 \%$ yield) as a colorless oil: $R_{\mathrm{f}} 0.35$ (hexane/EtOAc $\left.=7: 1\right) ;[\alpha]_{\mathrm{D}}^{25}-11.4(c 0.75$, $\mathrm{CHCl}_{3}$ ); IR (neat) $\nu_{\max } 3545,2925,2854,1742,1640,1466,1370$, $1238 \mathrm{~cm}^{-1} ;{ }^{1} \mathrm{H}$ NMR $\left(\mathrm{CDCl}_{3}, 400 \mathrm{MHz}\right) \delta 5.81$ (1H, ddt, $J=10.1$, 16.9, $6.8 \mathrm{~Hz}), 3.98(1 \mathrm{H}, \mathrm{dt}, J=4.9,5.7 \mathrm{~Hz}), 3.73(1 \mathrm{H}, \mathrm{q}, J=6.2$ $\mathrm{Hz}), 3.32(1 \mathrm{H}, \mathrm{dt}, J=5.7,6.3 \mathrm{~Hz}), 2.07(3 \mathrm{H}, \mathrm{s}), 2.06-2.00(2 \mathrm{H}, \mathrm{m})$, 1.94-1.75 (3H, m), 1.68 (1H, m), 1.59-1.17 (44H, m), $0.87(3 \mathrm{H}, \mathrm{t}, J$ $=7.0 \mathrm{~Hz}) ;{ }^{13} \mathrm{C} \mathrm{NMR}\left(\mathrm{CDCl}_{3}, 100 \mathrm{MHz}\right) \delta 170.9(\mathrm{C}), 139.3(\mathrm{CH})$, $114.1\left(\mathrm{CH}_{2}\right), 82.8(\mathrm{CH}), 80.5(\mathrm{CH}), 74.5(\mathrm{CH}), 74.1(\mathrm{CH}), 33.8$ $\left(\mathrm{CH}_{2}\right), 31.9\left(\mathrm{CH}_{2}\right), 31.1\left(\mathrm{CH}_{2}\right), 29.7\left(\mathrm{CH}_{2}\right), 29.65\left(\mathrm{CH}_{2}\right), 29.62$ $\left(\mathrm{CH}_{2}\right) \times 2,29.57\left(\mathrm{CH}_{2}\right) \times 4,29.54\left(\mathrm{CH}_{2}\right), 29.47\left(\mathrm{CH}_{2}\right) \times 2,29.46$ $\left(\mathrm{CH}_{2}\right), 29.3\left(\mathrm{CH}_{2}\right), 29.1\left(\mathrm{CH}_{2}\right), 28.9\left(\mathrm{CH}_{2}\right), 27.6\left(\mathrm{CH}_{2}\right), 26.6\left(\mathrm{CH}_{2}\right)$, $25.7\left(\mathrm{CH}_{2}\right), 25.4\left(\mathrm{CH}_{2}\right), 22.7\left(\mathrm{CH}_{2}\right), 21.2\left(\mathrm{CH}_{3}\right), 14.1\left(\mathrm{CH}_{3}\right) ; \mathrm{MS}$ (ESI-TOF) $m / z 531[\mathrm{M}+\mathrm{Na}]^{+}(100)$; HRMS (ESI-TOF) $m / z[\mathrm{M}+$ $\mathrm{Na}]^{+}$calcd for $\mathrm{C}_{32} \mathrm{H}_{60} \mathrm{O}_{4} \mathrm{Na} 531.4389$, found 531.4391; anal. calcd for $\mathrm{C}_{32} \mathrm{H}_{64} \mathrm{O}_{4}$ : C, 75.54; $\mathrm{H}, 11.89$. Found: $\mathrm{C}, 75.37 ; \mathrm{H}, 11.84$.

$(S)-3-((S)-13-H y d r o x y-13-((2 S, 5 R)-5-((S)-1-h y d r o x y t r i d e c y l)$

tetrahydrofuran-2-yl)tridecyl)-5-methylfuran-2(5H)-one (1). To a stirred solution of alcohol $12(24.1 \mathrm{mg}, 0.0474 \mathrm{mmol})$ in $\mathrm{CH}_{2} \mathrm{Cl}_{2}(0.948 \mathrm{~mL})$ was added DIBAH $(1.03 \mathrm{M}$ solution in hexane, $0.0920 \mathrm{~mL}, 0.0893 \mathrm{mmol}$ ) at $-78{ }^{\circ} \mathrm{C}$. After stirring for $45 \mathrm{~min}$, the reaction mixture was added $\mathrm{Na}_{2} \mathrm{SO}_{4} \cdot 10 \mathrm{H}_{2} \mathrm{O}(100$ $\mathrm{mg}$ ) slowly, diluted with $\mathrm{Et}_{2} \mathrm{O}$, and then warmed to room temperature. After stirring for $30 \mathrm{~min}$, the mixture was added $\mathrm{MgSO}_{4}$. After stirring for $15 \mathrm{~min}$, the resulting mixture passed through a pad of $\mathrm{Na}_{2} \mathrm{SO}_{4}$ and then concentrated in vacuo to give a crude diol which was used for the next step without further purification.

$\left[\mathrm{CpRu}\left(\mathrm{CH}_{3} \mathrm{CN}\right)_{3}\right]^{+} \mathrm{PF}_{6}{ }^{-}(2.1 \mathrm{mg}, 0.00484 \mathrm{mmol})$ was added to a stirred solution of the above crude diol and $(S)$-4-hydroxypent2-ynoate 3 (10.1 $\mathrm{mg}, 0.0711 \mathrm{mmol})$ in DMF (0.948 mL). The solution was allowed to stir at room temperature for $1 \mathrm{~h}$ before the reaction mixture was diluted with $\mathrm{Et}_{2} \mathrm{O}$ and passed through a plug of silica gel. The mixture was washed with $1.0 \mathrm{M} \mathrm{HCl}$ aq., $\mathrm{H}_{2} \mathrm{O}$, and brine, dried over anhydrous $\mathrm{MgSO}_{4}$ and $\mathrm{Na}_{2} \mathrm{SO}_{4}$, and then concentrated in vacuo to give a crude butenolide.

To a solution of the above crude butanolide and $\mathrm{TsNHNH}_{2}$ $(618 \mathrm{mg}, 3.32 \mathrm{mmol})$ in DME $(4.80 \mathrm{~mL})$ was added a solution of NaOAc (311 mg, $3.79 \mathrm{mmol})$ in $\mathrm{H}_{2} \mathrm{O}(4.80 \mathrm{~mL})$. The mixture was heated at $80{ }^{\circ} \mathrm{C}$ for $12 \mathrm{~h}$, and then cooled to room temperature. The mixture was diluted with $\mathrm{Et}_{2} \mathrm{O}$, washed with $\mathrm{H}_{2} \mathrm{O}$ and brine, dried over anhydrous $\mathrm{MgSO}_{4}$ and $\mathrm{Na}_{2} \mathrm{SO}_{4}$, and then concentrated in vacuo. The residue was purified with flash column chromatography on silica gel (hexane/EtOAc $=1: 1$ ) to give butenolide 1 (17.4 mg, 65\% yield for three steps) as a white waxy solid: $R_{\mathrm{f}} 0.40$ (hexane/EtOAc $\left.=1: 1\right) ; \mathrm{mp} 89-90^{\circ} \mathrm{C}$; $[\alpha]_{\mathrm{D}}^{25}+13.2(c$ $0.19, \mathrm{CHCl}_{3}$ ); IR (KBr) $\nu_{\max } 3450,2920,2849,1734,1468 \mathrm{~cm}^{-1}$; ${ }^{1} \mathrm{H} \mathrm{NMR}\left(\mathrm{CDCl}_{3}, 500 \mathrm{MHz}\right) \delta 6.98(1 \mathrm{H}, \mathrm{dt}, J=1.5,1.6 \mathrm{~Hz}), 4.99$ $(1 \mathrm{H}, \mathrm{ddq}, J=6.8,13.6,1.7 \mathrm{~Hz}), 3.90(1 \mathrm{H}, \mathrm{dt}, J=3.2,7.3 \mathrm{~Hz}), 3.83$ $(1 \mathrm{H}, \mathrm{m}), 3.81(1 \mathrm{H}, \mathrm{m}), 3.44(1 \mathrm{H}, \mathrm{m}), 2.27(1 \mathrm{H}, \mathrm{dt}, J=8.1,1.7 \mathrm{~Hz})$, $2.25(1 \mathrm{H}, \mathrm{dt}, J=8.1,1.7 \mathrm{~Hz}), 1.98-1.90(2 \mathrm{H}, \mathrm{m}), 1.88-1.66(4 \mathrm{H}$, $\mathrm{m}), 1.58-1.19(44 \mathrm{H}, \mathrm{m}), 1.40(3 \mathrm{H}, \mathrm{d}, J=6.9 \mathrm{~Hz}), 0.88(3 \mathrm{H}, \mathrm{t}, J=$ $6.9 \mathrm{~Hz}) ;{ }^{13} \mathrm{C} \mathrm{NMR}\left(\mathrm{CDCl}_{3}, 125 \mathrm{MHz}\right) \delta 173.9(\mathrm{C}), 148.8(\mathrm{CH})$, $134.4(\mathrm{C}), 82.7(\mathrm{CH}), 82.2(\mathrm{CH}), 77.4(\mathrm{CH}), 74.5(\mathrm{CH}), 72.3(\mathrm{CH})$,
$34.2\left(\mathrm{CH}_{2}\right), 33.1\left(\mathrm{CH}_{2}\right), 31.9\left(\mathrm{CH}_{2}\right), 29.69\left(\mathrm{CH}_{2}\right) \times 2,29.66\left(\mathrm{CH}_{2}\right)$ $\times 3,29.64\left(\mathrm{CH}_{2}\right), 29.60\left(\mathrm{CH}_{2}\right), 29.57\left(\mathrm{CH}_{2}\right) \times 2,29.56\left(\mathrm{CH}_{2}\right) \times 2$, $29.5\left(\mathrm{CH}_{2}\right), 29.34\left(\mathrm{CH}_{2}\right), 29.28\left(\mathrm{CH}_{2}\right), 29.2\left(\mathrm{CH}_{2}\right), 28.4\left(\mathrm{CH}_{2}\right), 27.4$ $\left(\mathrm{CH}_{2}\right), 25.9\left(\mathrm{CH}_{2}\right), 28.7\left(\mathrm{CH}_{2}\right), 25.2\left(\mathrm{CH}_{2}\right), 24.3\left(\mathrm{CH}_{2}\right), 22.7\left(\mathrm{CH}_{2}\right)$, $19.2\left(\mathrm{CH}_{3}\right), 14.1\left(\mathrm{CH}_{3}\right)$; MS (ESI-TOF) $\mathrm{m} / z 587[\mathrm{M}+\mathrm{Na}]^{+}(100)$; HRMS (ESI-TOF) $\mathrm{m} / z[\mathrm{M}+\mathrm{Na}]^{+}$calcd for $\mathrm{C}_{35} \mathrm{H}_{64} \mathrm{O}_{5} \mathrm{Na} 587.4651$, found 587.4655; anal. calcd for $\mathrm{C}_{35} \mathrm{H}_{64} \mathrm{O}_{5}$ : C, 74.42; $\mathrm{H}, 11.42$. Found: C, 74.32; H, 11.55 .

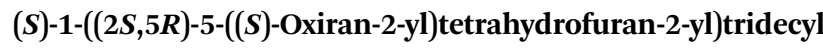
acetate (14). To a stirred solution of triol $13(12.2 \mathrm{mg}, 0.0369$ $\mathrm{mmol})$ in 2,2-dimethoxypropane $(1.20 \mathrm{~mL})$ was added $p \mathrm{TsOH} \cdot \mathrm{H}_{2} \mathrm{O}(0.7 \mathrm{mg}, 0.00368 \mathrm{mmol})$ at room temperature. After stirring for $12 \mathrm{~h}$, the mixture was diluted with $\mathrm{Et}_{2} \mathrm{O}$, washed with $\mathrm{H}_{2} \mathrm{O}$ and brine, dried over anhydrous $\mathrm{MgSO}_{4}$ and $\mathrm{Na}_{2} \mathrm{SO}_{4}$, and then concentrated in vacuo to give a crude acetonide which was used for the next step without further purification.

Acetic anhydride $(0.369 \mathrm{~mL}, 3.90 \mathrm{mmol})$ was added to a stirred solution of the above crude acetonide in pyridine $(0.369 \mathrm{~mL}$, $4.58 \mathrm{mmol}$ ) at room temperature. After stirring for $12 \mathrm{~h}$, the mixture was concentrated in vacuo to give a crude acetate which was used for the next step without further purification.

To the above crude acetate was added $80 \%$ AcOH aq. (0.369 $\mathrm{mL}$ ) at room temperature. The mixture was warmed to $50{ }^{\circ} \mathrm{C}$ and after $40 \mathrm{~min}$ recooled to room temperature. The mixture was diluted with EtOAc, washed with saturated aqueous $\mathrm{NaHCO}_{3}$ solution $\mathrm{H}_{2} \mathrm{O}$ and brine, dried over anhydrous $\mathrm{MgSO}_{4}$ and $\mathrm{Na}_{2} \mathrm{SO}_{4}$, and then concentrated in vacuo to give a crude diol which was used for the next step without further purification.

To a stirred solution of the above crude diol in $\mathrm{CH}_{2} \mathrm{Cl}_{2}$ $(0.0740 \mathrm{~mL})$ were added $\mathrm{Et}_{3} \mathrm{~N}(0.0310 \mathrm{~mL}, 0.222 \mathrm{mmol}), \mathrm{TBSCl}$ (16.7 $\mathrm{mg}, 0.111 \mathrm{mmol}$ ), and DMAP (0.5 mg, $0.00409 \mathrm{mmol})$ at $0{ }^{\circ} \mathrm{C}$ and then warmed to room temperature. After stirring for $3.5 \mathrm{~h}$, the mixture was quenched with saturated aqueous $\mathrm{NaHCO}_{3}$ solution, diluted with $\mathrm{Et}_{2} \mathrm{O}$, washed with $\mathrm{H}_{2} \mathrm{O}$, and brine, dried over anhydrous $\mathrm{MgSO}_{4}$ and $\mathrm{Na}_{2} \mathrm{SO}_{4}$, and then concentrated in vacuo to give a crude TBS ether which was used for the next step without further purification.

To a stirred solution of the above crude TBS ether in $\mathrm{CH}_{2} \mathrm{Cl}_{2}$ $(0.369 \mathrm{~mL})$ were added $\mathrm{Et}_{3} \mathrm{~N}(0.0206 \mathrm{~mL}, 0.148 \mathrm{mmol})$ and $\mathrm{MsCl}$ $(0.00571 \mathrm{~mL}, 0.0738 \mathrm{mmol})$ at $0{ }^{\circ} \mathrm{C}$ and then warmed to room temperature. After stirring for $1 \mathrm{~h}$, the mixture was quenched with saturated aqueous $\mathrm{NaHCO}_{3}$ solution, diluted with $\mathrm{Et}_{2} \mathrm{O}$, washed with $\mathrm{H}_{2} \mathrm{O}$, and brine, dried over anhydrous $\mathrm{MgSO}_{4}$ and $\mathrm{Na}_{2} \mathrm{SO}_{4}$, and then concentrated in vacuo to give a crude mesylate which was used for the next step without further purification.

To a stirred solution of the above crude mesylate in THF (0.369 $\mathrm{mL})$ were added TBAF (1.00 M solution in THF, 0.0923 $\mathrm{mL}, 0.0923 \mathrm{mmol}$ ) at room temperature. After stirring for $1 \mathrm{~h}$, the mixture was warmed to $50{ }^{\circ} \mathrm{C}$ and stirred for $12 \mathrm{~h}$. The mixture was diluted with $\mathrm{Et}_{2} \mathrm{O}$, washed with $\mathrm{H}_{2} \mathrm{O}$, and brine, dried over anhydrous $\mathrm{MgSO}_{4}$ and $\mathrm{Na}_{2} \mathrm{SO}_{4}$, and then concentrated in vacuo. The residue was purified with flash column chromatography on silica gel (hexane/EtOAc $=2: 1$ ) to give epoxide 14 (9.8 mg, 75\% yield for six steps) as a colorless oil: $R_{\mathrm{f}}$ 0.55 (hexane/EtOAc = $1: 1) ;[\alpha]_{\mathrm{D}}^{25}-13.4\left(c 0.95, \mathrm{CHCl}_{3}\right)$; IR (neat) $\nu_{\max } 2925,2854,1739,1467,1372,1240,1075,1026 \mathrm{~cm}^{-1} ;{ }^{1} \mathrm{H}$ NMR $\left(\mathrm{CDCl}_{3}, 400 \mathrm{MHz}\right) \delta 4.87(1 \mathrm{H}, \mathrm{dt}, J=7.7,5.3 \mathrm{~Hz}), 4.06(1 \mathrm{H}$, 
$\mathrm{dt}, J=5.3,6.6 \mathrm{~Hz}), 3.91(1 \mathrm{H}, \mathrm{dt}, J=4.8,6.6 \mathrm{~Hz}), 2.99(1 \mathrm{H}, \mathrm{ddd}, J$ $=2.7,4.0,4.8 \mathrm{~Hz}), 2.79(1 \mathrm{H}, \mathrm{dd}, J=4.0,4.9 \mathrm{~Hz}), 2.58(1 \mathrm{H}, \mathrm{dd}, J=$ 2.7, $4.9 \mathrm{~Hz}), 2.09$ (3H, s), 2.06-1.96 (2H, m), 1.76 (1H, m), 1.65 (1H, m), 1.35-1.19 (22H, m), $0.88(3 \mathrm{H}, \mathrm{t}, J=6.7 \mathrm{~Hz}) ;{ }^{13} \mathrm{C} \mathrm{NMR}$ $\left(\mathrm{CDCl}_{3}, 100 \mathrm{MHz}\right) \delta 170.9(\mathrm{C}), 80.1(\mathrm{CH}), 78.9(\mathrm{CH}), 75.1(\mathrm{CH})$, $53.1(\mathrm{CH}), 45.3\left(\mathrm{CH}_{2}\right), 31.9\left(\mathrm{CH}_{2}\right), 31.0\left(\mathrm{CH}_{2}\right), 29.6\left(\mathrm{CH}_{2}\right), 29.6$ $\left(\mathrm{CH}_{2}\right) \times 2,29.5\left(\mathrm{CH}_{2}\right), 29.4\left(\mathrm{CH}_{2}\right) \times 2,29.3\left(\mathrm{CH}_{2}\right), 27.8\left(\mathrm{CH}_{2}\right)$, $27.6\left(\mathrm{CH}_{2}\right), 25.4\left(\mathrm{CH}_{2}\right), 22.6\left(\mathrm{CH}_{2}\right), 21.1\left(\mathrm{CH}_{3}\right), 14.1\left(\mathrm{CH}_{3}\right) ; \mathrm{MS}$ (ESI-TOF) $m / z 377[\mathrm{M}+\mathrm{Na}]^{+}$(100); HRMS (ESI-TOF) $m / z[\mathrm{M}+$ $\mathrm{Na}]^{+}$calcd for $\mathrm{C}_{21} \mathrm{H}_{38} \mathrm{O}_{4} \mathrm{Na} 377.2668$, found 377.2671 ; anal. calcd for $\mathrm{C}_{21} \mathrm{H}_{38} \mathrm{O}_{4}$ : C, 71.14; $\mathrm{H}, 10.80$. Found: $\mathrm{C}, 71.08 ; \mathrm{H}, 10.72$.

$(S)-1-((2 R, 5 S)-5-((S)-1-H y d r o x y t r i d e c y l) t e t r a h y d r o f u r a n-2-y l)$ tridec-12-en-1-ol (15). At $-60{ }^{\circ} \mathrm{C}$, undec-10-enylmagnesium bromide (1.00 $\mathrm{M}$ solution in THF, $11.0 \mathrm{~mL}, 11.0 \mathrm{mmol}$ ) was added dropwise to a suspension of CuI $(1.05 \mathrm{~g}, 5.51 \mathrm{mmol})$ in THF $(30.0 \mathrm{~mL})$. The mixture was warmed to $-30{ }^{\circ} \mathrm{C}$ and after $20 \mathrm{~min}$ recooled to $-60{ }^{\circ} \mathrm{C}$ whereupon a solution of epoxide 14 (649 mg, $1.83 \mathrm{mmol}$ ) in THF (6.60 mL) was added dropwise. The mixture was allowed to warm to $-20{ }^{\circ} \mathrm{C}$ over $4 \mathrm{~h}$. Saturated aqueous $\mathrm{NH}_{4} \mathrm{Cl}$ solution/ $\mathrm{NH}_{3}(8: 1,36.6 \mathrm{~mL})$ was added to the reaction mixture. The mixture was diluted with $\mathrm{Et}_{2} \mathrm{O}$, washed with saturated aqueous $\mathrm{NH}_{4} \mathrm{Cl}$ solution, $\mathrm{H}_{2} \mathrm{O}$, and brine, dried over anhydrous $\mathrm{MgSO}_{4}$ and $\mathrm{Na}_{2} \mathrm{SO}_{4}$, and then concentrated in vacuo. The residue was purified with flash column chromatography on silica gel (hexane/EtOAc $=7: 1$ ) to give alcohol 15 (658 mg, 77\% yield) as a white waxy solid: $R_{\mathrm{f}} 0.20$ (hexane/EtOAc $=4: 1)$; $\mathrm{mp} 75-76{ }^{\circ} \mathrm{C} ;[\alpha]_{\mathrm{D}}^{25}-9.3\left(c 0.77, \mathrm{CHCl}_{3}\right)$; IR $(\mathrm{KBr}) \nu_{\max }$ 3434, 2918, 2850, 1642, $1467 \mathrm{~cm}^{-1} ;{ }^{1} \mathrm{H} \mathrm{NMR}\left(\mathrm{CDCl}_{3}, 400 \mathrm{MHz}\right)$ $\delta 5.81(1 \mathrm{H}, \mathrm{ddt}, J=10.2,17.1,6.6 \mathrm{~Hz}), 4.99(1 \mathrm{H}, \mathrm{ddt}, J=2.2$, $17.1,1.6 \mathrm{~Hz}), 4.92(1 \mathrm{H}, \mathrm{ddt}, J=2.2,10.2,1.2 \mathrm{~Hz}), 3.87$ (1H, ddd, $J$ $=3.4,6.0,9.2 \mathrm{~Hz}), 3.85-3.77(2 \mathrm{H}, \mathrm{m}), 3.39(1 \mathrm{H}, \mathrm{dt}, J=5.4,6.6$ $\mathrm{Hz}), 2.16-1.79(8 \mathrm{H}, \mathrm{m}), 1.63(1 \mathrm{H}, \mathrm{m}), 1.57-1.19(39 \mathrm{H}, \mathrm{m}), 0.88$ $(3 \mathrm{H}, \mathrm{t}, J=6.7 \mathrm{~Hz}) ;{ }^{13} \mathrm{C} \mathrm{NMR}\left(\mathrm{CDCl}_{3}, 100 \mathrm{MHz}\right) \delta 139.2(\mathrm{CH})$, $114.1\left(\mathrm{CH}_{2}\right), 83.2(\mathrm{CH}), 82.1(\mathrm{CH}), 74.3(\mathrm{CH}), 71.5(\mathrm{CH}), 33.8$ $\left(\mathrm{CH}_{2}\right), 33.2\left(\mathrm{CH}_{2}\right), 32.5\left(\mathrm{CH}_{2}\right), 31.9\left(\mathrm{CH}_{2}\right), 29.71\left(\mathrm{CH}_{2}\right), 29.66$ $\left(\mathrm{CH}_{2}\right), 29.64\left(\mathrm{CH}_{2}\right), 29.63\left(\mathrm{CH}_{2}\right), 29.61\left(\mathrm{CH}_{2}\right), 29.57\left(\mathrm{CH}_{2}\right), 29.56$ $\left(\mathrm{CH}_{2}\right) \times 2,29.53\left(\mathrm{CH}_{2}\right), 29.47\left(\mathrm{CH}_{2}\right), 29.3\left(\mathrm{CH}_{2}\right), 29.1\left(\mathrm{CH}_{2}\right), 28.9$ $\left(\mathrm{CH}_{2}\right)$, $28.6\left(\mathrm{CH}_{2}\right), 28.0\left(\mathrm{CH}_{2}\right), 26.0\left(\mathrm{CH}_{2}\right), 25.6\left(\mathrm{CH}_{2}\right), 25.2\left(\mathrm{CH}_{2}\right)$, $22.7\left(\mathrm{CH}_{2}\right), 14.0\left(\mathrm{CH}_{3}\right)$; MS (ESI-TOF) $\mathrm{m} / z 489[\mathrm{M}+\mathrm{Na}]^{+}(100)$; HRMS (ESI-TOF) $m / z[\mathrm{M}+\mathrm{Na}]^{+}$calcd for $\mathrm{C}_{30} \mathrm{H}_{58} \mathrm{O}_{3} \mathrm{Na} 489.4284$, found 489.4284; anal. calcd for $\mathrm{C}_{30} \mathrm{H}_{58} \mathrm{O}_{3}$ : C, 77.19; $\mathrm{H}, 12.52$. Found: C, 76.91; H, 12.22.

$(S)-3-((S)-13-H y d r o x y-13-((2 R, 5 S)-5-((S)-1-h y d r o x y t r i d e c y l)$ tetrahydrofuran-2-yl)tridecyl)-5-methylfuran-2(5H)-one $\left[\mathrm{CpRu}\left(\mathrm{CH}_{3} \mathrm{CN}\right)_{3}\right]^{+} \mathrm{PF}_{6}^{-}(22.3 \mathrm{mg}, 0.0513 \mathrm{mmol})$ was added to a stirred solution of the above crude diol and $(S)$-4-hydroxypent2-ynoate 3 (110 mg, $0.774 \mathrm{mmol})$ in DMF $(5.10 \mathrm{~mL})$. The solution was allowed to stir at room temperature for $1 \mathrm{~h}$ before the reaction mixture was diluted with $\mathrm{Et}_{2} \mathrm{O}$ and passed through a plug of silica gel. The mixture was washed with $1.0 \mathrm{M} \mathrm{HCl} \mathrm{aq.,}$ $\mathrm{H}_{2} \mathrm{O}$, and brine, dried over anhydrous $\mathrm{MgSO}_{4}$ and $\mathrm{Na}_{2} \mathrm{SO}_{4}$, and then concentrated in vacuo to give a crude butenolide.

To a solution of the above crude butanolide and $\mathrm{TsNHNH}_{2}$ $(3.83 \mathrm{~g}, 20.6 \mathrm{mmol})$ in DME $(25.7 \mathrm{~mL})$ was added a solution of NaOAc $(2.11 \mathrm{~g}, 25.7 \mathrm{mmol})$ in $\mathrm{H}_{2} \mathrm{O}(25.7 \mathrm{~mL})$. The mixture was heated at $80{ }^{\circ} \mathrm{C}$ for $3 \mathrm{~h}$, and then cooled to room temperature. The mixture was diluted with $\mathrm{Et}_{2} \mathrm{O}$, washed with $\mathrm{H}_{2} \mathrm{O}$ and brine, dried over anhydrous $\mathrm{MgSO}_{4}$ and $\mathrm{Na}_{2} \mathrm{SO}_{4}$, and then concentrated in vacuo. The residue was purified with flash column chromatography on silica gel (hexane/EtOAc $=1: 1$ ) to give butenolide 2 (260 mg, 89\% yield for two steps) as a white waxy solid: $R_{\mathrm{f}} 0.40$ (hexane/EtOAc $\left.=1: 1\right) ; \operatorname{mp~} 86-87^{\circ} \mathrm{C} ;[\alpha]_{\mathrm{D}}^{25}+4.5(c$ $0.39, \mathrm{CHCl}_{3}$ ); IR (KBr) $\nu_{\text {max }} 3440,2920,2851,1740,1469 \mathrm{~cm}^{-1}$; ${ }^{1} \mathrm{H} \mathrm{NMR}\left(\mathrm{CDCl}_{3}, 500 \mathrm{MHz}\right) \delta 6.98(1 \mathrm{H}, \mathrm{dt}, J=1.6,1.5 \mathrm{~Hz}), 4.99$ $(1 \mathrm{H}, \mathrm{ddq}, J=6.8,13.6,1.6 \mathrm{~Hz}), 3.87(1 \mathrm{H}, \mathrm{ddd}, J=3.4,6.0,9.3$ $\mathrm{Hz}), 3.82(1 \mathrm{H}, \mathrm{dt}, J=8.2,6.7 \mathrm{~Hz}), 3.80(1 \mathrm{H}, \mathrm{ddd}, J=3.6,6.8,9.3$ $\mathrm{Hz}), 3.39(1 \mathrm{H}, \mathrm{dt}, J=6.5,6.7 \mathrm{~Hz}), 2.27(1 \mathrm{H}, \mathrm{dt}, J=8.0,1.6 \mathrm{~Hz})$, $2.25(1 \mathrm{H}, \mathrm{dt}, J=8.0,1.6 \mathrm{~Hz}), 2.02-1.81(2 \mathrm{H}, \mathrm{m}), 1.92(2 \mathrm{H}, \mathrm{brs})$, 1.68-1.56 (2H, m), 1.54-1.18 (44H, m), $1.40(3 \mathrm{H}, \mathrm{d}, J=6.8 \mathrm{~Hz})$, $0.88(3 \mathrm{H}, \mathrm{t}, J=6.9 \mathrm{~Hz}) ;{ }^{13} \mathrm{C} \mathrm{NMR}\left(\mathrm{CDCl}_{3}, 125 \mathrm{MHz}\right) \delta 173.9(\mathrm{C})$, 148.8 (CH), 134.3 (C), 83.2 (CH), 82.1 (CH), 77.4 (CH), 74.3 (CH), $71.6(\mathrm{CH}), 33.2\left(\mathrm{CH}_{2}\right), 32.6\left(\mathrm{CH}_{2}\right), 31.9\left(\mathrm{CH}_{2}\right), 29.70\left(\mathrm{CH}_{2}\right), 29.66$ $\left(\mathrm{CH}_{2}\right) \times 2,29.64\left(\mathrm{CH}_{2}\right), 29.62\left(\mathrm{CH}_{2}\right), 29.60\left(\mathrm{CH}_{2}\right), 29.57\left(\mathrm{CH}_{2}\right) \times$ 3, $29.6\left(\mathrm{CH}_{2}\right), 29.53\left(\mathrm{CH}_{2}\right), 29.49\left(\mathrm{CH}_{2}\right), 29.34\left(\mathrm{CH}_{2}\right), 29.28\left(\mathrm{CH}_{2}\right)$, $29.2\left(\mathrm{CH}_{2}\right), 28.6\left(\mathrm{CH}_{2}\right), 27.4\left(\mathrm{CH}_{2}\right), 26.0\left(\mathrm{CH}_{2}\right), 25.6\left(\mathrm{CH}_{2}\right), 25.3$ $\left(\mathrm{CH}_{2}\right), 25.2\left(\mathrm{CH}_{2}\right), 22.7\left(\mathrm{CH}_{2}\right), 19.2\left(\mathrm{CH}_{3}\right), 14.1\left(\mathrm{CH}_{3}\right)$; MS (ESITOF) $m / z 587[\mathrm{M}+\mathrm{Na}]^{+}(100)$; HRMS (ESI-TOF) $m / z[\mathrm{M}+\mathrm{Na}]^{+}$ calcd for $\mathrm{C}_{35} \mathrm{H}_{64} \mathrm{O}_{5} \mathrm{Na} 587.4651$, found 587.4659; anal. calcd for $\mathrm{C}_{35} \mathrm{H}_{64} \mathrm{O}_{5}$ : C, 74.42; H, 11.42. Found: C, 74.17; H, 11.31.

\section{Conflicts of interest}

There are no conflicts to declare.

\section{Notes and references}

1 (a) S. D. Jolad, J. J. Hoffman, K. H. Schram, J. R. Cole, M. S. Tempesta, G. R. Kriek and R. B. Bates, J. Org. Chem., 1982, 47, 3151; (b) F. Q. Alali, X.-X. Liu and J. L. McLaughlin, J. Nat. Prod., 1999, 62, 504; (c) N. Li, Z. Shi, Y. Tang, J. Chen and X. Li, Beilstein J. Org. Chem., 2008, 4, 1.

2 (a) J. K. Rupprecht, Y.-H. Hui and J. L. McLaughlin, J. Nat. Prod., 1990, 53, 237; (b) X. Fang, M. J. Rieser, Z. Gu, G. Zhao and J. L. McLaughlin, Phytochem. Anal., 1993, 4, 27; (c) S. Hoppen, U. Emde, T. Friedrich, L. Grubert and U. Koert, Angew. Chem., Int. Ed., 2000, 39, 2099; (d) N. Ichimaru, M. Murai, M. Abe, T. Hamada, Y. Yamada, S. Makino, T. Nishioka, H. Makabe, A. Makino, T. Kobayashi and H. Miyoshi, Biochemisty, 2005, 44, 816.

3 (a) T. Friedrich, P. van Heek, H. Leif, T. Ohnishi, E. Forche, B. Kunze, R. Jansen, W. Trowitzsch-Kienast, G. Höfle, H. Reichenbach and H. Weiss, Eur. J. Biochem., 1994, 219, 691; (b) M. Degli Esposti, Biochim. Biophys. Acta, 1998, 1364, 222; (c) H. Miyoshi, Biochim. Biophys. Acta, 1998, 1364, 236.

4 M. Abe, M. Murai, N. Ichimaru, A. Kenmochi, T. Yoshida, A. Kubo, Y. Kimura, A. Moroda, H. Makabe, T. Nishioka and H. Miyoshi, Biochemistry, 2005, 44, 14898.

5 C. Gleye, P. Duret, A. Laurens, R. Hocquemiller and A. Cavé, J. Nat. Prod., 1998, 61, 576.

6 (a) H. Makabe, Y. Hattori, A. Tanaka and T. Oritani, Org. Lett., 2002, 4, 2613; (b) T. J. Donohoe and S. Butterworth, Angew. Chem., Int. Ed., 2005, 44, 4766; (c) H. Göksel and 
C. B. W. Stark, Org. Lett., 2006, 8, 3433; (d) H. Konno, Y. Okuno, H. Makabe, K. Nosaka, A. Onishi, Y. Abe, A. Sugimoto and K. Akaji, Tetrahedron Lett., 2008, 49, 782.

7 K. Ota, T. Yamashita, S. Kohno, A. Miura, K. Kamaike and H. Miyaoka, Org. Biomol. Chem., 2018, 16, 3018.

8 C.-C. Liaw, Y.-L. Yang, M. Chen, F.-R. Chang, S.-L. Chen, S.-H. Wu and Y.-C. Wu, J. Nat. Prod., 2008, 71, 764.

9 (a) L. Born, F. Lieb, J. P. Lorentzen, H. Moeschler, M. Nonfon, R. Soellner and D. Wendisch, Planta Med., 1990, 56, 312; (b)

Y. Fujimoto, C. Murasaki, H. Shimada, S. Nishioka, K. Kakinuma, S. Singh, M. Singh, Y. K. Gupta and M. Sahai, Chem. Pharm. Bull., 1994, 42, 1175.

10 B. N. Su, E. J. Park, Z. H. Mbwambo, B. D. Santarsiero, A. D. Mesecar, H. H. S. Fong, J. M. Pezzuto and A. D. Kinghorn, J. Nat. Prod., 2002, 65, 1278.
11 B. M. Trost, G. D. Probst and A. Schoop, J. Am. Chem. Soc., 1998, 120, 9228.

12 V. M. T. Carneiro, C. M. Avila, M. J. Balunas, W. H. Gerwick and R. A. Pilli, J. Org. Chem., 2014, 79, 630.

13 T. Katsuki and K. B. Sharpless, J. Am. Chem. Soc., 1980, 102, 5974.

14 T. Ema, D. Tanida and T. Sakai, Org. Lett., 2006, 8, 3773.

15 D. R. Williams, M. G. Fromhold and J. D. Earley, Org. Lett., 2001, 3, 2721.

16 K. Ota, CCDC 1950967: CSD Communication, 2019, DOI: 10.5517/ccdc.csd.cc23h4f6.

17 (a) A. R. L. Cecil, Y. Hu, M. J. Vicent, R. Duncan and R. C. D. Brown, J. Org. Chem., 2004, 69, 3368; (b) S. B. A. Ghani, J. M. Chapman, B. Figadëre, J. M. Herniman, G. J. Langley, S. Niemann and R. C. D. Brown, J. Org. Chem., 2009, 74, 6924. 